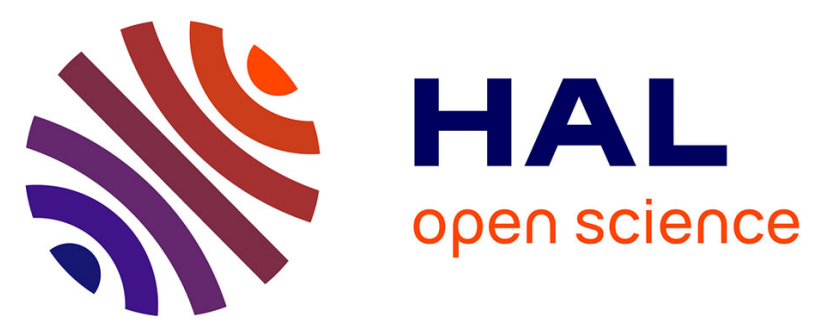

\title{
Coordination Chemistry and Diphenylacetylene Hydrogenation Catalysis of Planar Chiral Ferrocenylphosphane-Thioether Ligands with Cyclooctadieneiridium(I)
}

Raluca Malacea, Eric Manoury, Lucie Routaboul, Jean-Claude Daran, Rinaldo

Poli, John P Dunne, Adrian C Withwood, Cyril Godard, Simon B Duckett

\section{To cite this version:}

Raluca Malacea, Eric Manoury, Lucie Routaboul, Jean-Claude Daran, Rinaldo Poli, et al.. Coordination Chemistry and Diphenylacetylene Hydrogenation Catalysis of Planar Chiral FerrocenylphosphaneThioether Ligands with Cyclooctadieneiridium(I). European Journal of Inorganic Chemistry, 2006, 2006 (9), pp.1803-1816. 10.1002/ejic.200600065 . hal-03196083

\section{HAL Id: hal-03196083 https://hal.science/hal-03196083}

Submitted on 12 Apr 2021

HAL is a multi-disciplinary open access archive for the deposit and dissemination of scientific research documents, whether they are published or not. The documents may come from teaching and research institutions in France or abroad, or from public or private research centers.
L'archive ouverte pluridisciplinaire HAL, est destinée au dépôt et à la diffusion de documents scientifiques de niveau recherche, publiés ou non, émanant des établissements d'enseignement et de recherche français ou étrangers, des laboratoires publics ou privés. 


\title{
Coordination chemistry and diphenylacetylene hydrogenation catalysis of planar chiral ferrocenylphosphine-thioether ligands with cyclooctadieneiridium(I)
}

\author{
Raluca Malacea, ${ }^{[a]}$ Eric Manoury, ${ }^{*[a]}$ Lucie Routaboul, ${ }^{[a]}$ Jean-Claude Daran, ${ }^{[a]}$ \\ Rinaldo Poli, ${ }^{[a]}$ John P. Dunne, ${ }^{[b]}$ Adrian C. Withwood, ${ }^{[b]}$ Cyril Godard, ${ }^{[b]}$ and
}

Simon B. Duckett ${ }^{[b]}$

Keywords

Ferrocenylphosphine ligands, Hemilability, Hydrogenation, Iridium, Planar chirality, Thioether ligands

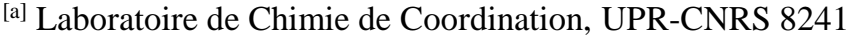

205 Route de Narbonne, 31077 Toulouse Cedex, France

Fax : +33-5/61553131

E-mail : manoury@1cc-toulouse.fr

[b] Department of Chemistry, University of York,

YO10 5DD, United Kingdom

E-mail : sbd3@york.ac.uk

Supporting Information for this article is available on the

WWW under http://www.eurjic.org or from the author.
} 


\section{Abstract}

Reaction of the P,S ligands $\mathrm{CpFe}\left\{1,2-\mathrm{C}_{5} \mathrm{H}_{3}\left(\mathrm{PPh}_{2}\right)\left(\mathrm{CH}_{2} \mathrm{SR}\right)\right\},(\mathbf{1}-\mathbf{R} ; \mathrm{R}=\mathrm{Et}, \mathrm{Ph}, t \mathrm{Bu})$, with 0.5 equivalents of $[\operatorname{Ir}(\mathrm{COD}) \mathrm{Cl}]_{2}$ (metal/ligand $\left.=1 / 1\right)$ furnishes the stable mononuclear adducts $[\operatorname{Ir}(\mathrm{COD}) \mathrm{Cl}(\mathbf{1 - R})], \mathbf{2}-\mathbf{R}$, in high yields. Molecular structures of the three complexes 2-R have been determined by single crystal X-Ray diffraction. Compounds 2-Et and 2-Ph have similar 5-coordinate molecular structures, with an intermediate coordination geometry between a distorted trigonal bipyramid and a distorted square pyramid. In the solid state, the sulfur atom chirality ( $\mathrm{R}$ group exo, lone pair endo and parallel to the $\mathrm{Cp}-\mathrm{Fe}$ axis) as well the iridium chirality $(\mathrm{Cl}$ atom exo relative to the ferrocene group) is controlled by the ligand planar chirality. In solution, only one diastereoisomer is observed in both cases, indicating that the geometries observed in the solid state are maintained in solution or that the different species are in rapid exchange on the NMR time scale. Complex 2-tBu, on the other hand, shows a 4-coordinate square planar molecular structure with a dangling thioether moiety, probably for steric reasons. For metal/ligand ratios greater than 1 , compounds $\left[\operatorname{Ir}(C O D)\left\{\kappa^{2}-\right.\right.$ $P: S-(\mathbf{1}-\mathbf{R})\}]^{+}\left[\operatorname{Ir}(\mathrm{COD}) \mathrm{Cl}_{2}\right]^{-}$(3-R) are obtained, resulting from the chloride abstraction by the excess iridium metal on complex 2-R. The structure of 3-Ph was confirmed by single crystal X-ray diffraction. A rapid equilibration between $\mathbf{2}-\mathbf{R}$ and $\mathbf{3}-\mathbf{R}$ gives rise to only one set of NMR signals for each metal/ligand ratio. For ligand 1-tBu, a similar equilibration between 2$t \mathbf{B u}$ and 3-tBu is again observed, in addition to a slower equilibration with a third product, $[\operatorname{Ir}(\mathrm{COD}) \mathrm{Cl}](\mu-\mathbf{1}-\mathbf{R})[\operatorname{Ir}(\mathrm{COD}) \mathrm{Cl}](\mathbf{4}-\mathrm{t} \mathbf{B u})$, which is proposed to contain a bridging $\mathrm{P}, \mathrm{S}$ ligand spanning two Ir centres. Complex 2-Ph reacts with $[\mathrm{Rh}(\mathrm{COD}) \mathrm{Cl}]_{2}$ to give only the heterometallic ionic pair $\left[\operatorname{Ir}(\mathrm{COD})\left\{\kappa^{2}-P: S-(\mathbf{1}-\mathbf{P h})\right\}\right]\left[\mathrm{Rh}(\mathrm{COD}) \mathrm{Cl}_{2}\right]$ without transfer of ligand 1-Ph from $\mathrm{Ir}$ to $\mathrm{Rh}$. Furthermore, the rhodium complex $\mathrm{RhCl}(\mathrm{COD})(\mathbf{1 - P h})$ reacts quantitatively with $[\operatorname{Ir}(\mathrm{COD}) \mathrm{Cl}]_{2}$ at $\mathrm{RT}$ to yield $\mathbf{2 - P h}$ and $[\mathrm{Rh}(\mathrm{COD}) \mathrm{Cl}]_{2}$, thereby illustrating 
the much stronger affinity of ligands 1-Ph for iridium compared to rhodium. Finally, complexes 2-t $\mathbf{B u}$ and $\mathbf{2 - P h}$ were found to be efficient catalysts for diphenylacetylene hydrogenation, affording a mixture of monohydrogenation (both E- and Z-stilbene) and dihydrogenation (1,2-diphenylethane) products.

\section{Introduction}

The coordination chemistry of iridium has been widely studied during the last few decades, in part because of numerous applications that have been found in various catalytic systems $^{[1]}$ since the pioneering work of Crabtree et al. ${ }^{[2]}$ In particular, iridium has been successfully applied to asymmetric catalyses, such as olefin hydrogenation, ${ }^{[3-12]} \mathrm{C}=\mathrm{N}$ hydrogenation, ${ }^{[13-21]}$ transfer hydrogenation ${ }^{[22-28]}$ and allylic substitution. ${ }^{[29-40]}$ Furthermore, the largest scale industrial enantioselective catalytic process involves an iridium-based hydrogenation step in the synthesis of chiral herbicide (1S)-Metolachlor. ${ }^{[41,42]}$ Although many catalytic systems are generated in situ by the ligand addition to the readily available chloro(cycloocta-1,5-diene)iridium dimer, a good number of ligand adducts have been isolated and crystallographically characterized. When the supporting ligand (L-L') is bidentate, several species can be envisaged depending on the ability of the ligand to act in a monodentate or bidentate fashion and on the competition between the donor atoms and the chloride ion for the metal center. These species correspond to 5 -coordinate $\operatorname{Ir}\left(\kappa^{2}-\mathrm{L}-\right.$ $\left.\mathrm{L}^{\prime}\right)(\mathrm{COD}) \mathrm{Cl}$, 4-coordinate neutral $\operatorname{Ir}\left(\kappa^{1}-\mathrm{L}^{-\mathrm{L}^{\prime}}\right)(\mathrm{COD}) \mathrm{Cl}$ with a dangling $\mathrm{L}$ or $\mathrm{L}^{\prime}$ donor atom, and 4-coordinate ionic $\left[\operatorname{Ir}\left(\kappa^{2}-\mathrm{L}-\mathrm{L}^{\prime}\right)(\mathrm{COD})\right]^{+} \mathrm{Cl}^{-}$. Whereas several solid state structures are available for 5-coordinate complexes ${ }^{[43-47]}$ and an example is also reported for neutral 4coordinate structure with a dangling phosphino-ester ligand, ${ }^{[48]}$ no examples are known, to the best of our knowledge, of 4-coordinate ionic $\left[\operatorname{Ir}\left(\kappa^{2}-\mathrm{L}-\mathrm{L}^{\prime}\right)(\mathrm{COD})\right]^{+}$complexes with chloride as 
counter-ion (though they are known for rhodium). ${ }^{[49-51]}$ Whether, for a given metal/ligand combination, the solid state structure is maintained in solution and whether it is solvent dependent, or whether equilibria between different structures are established, has not been the subject of detailed studies to the best of our knowledge. In addition, how the ligand stereoelectronic properties may influence this structural choice is also an obscure point.

The coordination chemistry of sulphur-containing ligands, ${ }^{[52,53]}$ as well as their potential in homogenous catalysis ${ }^{[54,55]}$ have recently attracted much interest, amongst other things because the sulphur atom could become asymmetric upon coodination to a metal. We have recently reported the synthesis of a family of planar-chiral P,S ligands, namely (R/S)-2diphenylphosphino-(R-thiomethyl)ferrocenes, 1-R, for instance with $\mathrm{R}=\mathrm{Et}, t \mathrm{Bu}, \mathrm{Ph}$ ), which proved to be very efficient in palladium-based asymmetric allylic alkylation. ${ }^{[56]}$ As a first step toward the development of iridium-based catalytic systems, we wished to explore the iridium coordination chemistry of such ligands, with a particular focus on the stoechiometry, stereochemistry, potential (hemi)lability, etc. In this paper, we describe the synthesis and structure of a family of iridium complexes produced upon reaction of the racemic $\mathbf{1 - R}(\mathrm{R}=$ $\mathrm{Et}, t \mathrm{Bu}, \mathrm{Ph})$ ligands with the cyclooctadieneiridium(I) moiety. We place particular emphasis on probing the relationship between the solution behaviour, the solid state structure, and the nature of the R substituent on the ferrocenyl thioether function. New structural features and an unsuspected complex solution behaviour have been found through these investigations. Preliminary results on the catalytic diphenylacetylene hydrogenation reaction are also reported. Although the COD ligand is replaced by other ligands or substrates under most catalytic conditions (e.g. it is hydrogenated to cyclooctane under hydrogenation conditions) the structural and dynamic features observed for the pre-catalyst (i.e., the coordination stereoselectivity, the hemilability) are potentially relevant to the behaviour that one may expect under catalytic conditions. 


\section{Results}

\section{(a) Syntheses.}

Addition of the 2 equivalents of the bidentate ligands $\mathrm{CpFe}\left[1,2-\mathrm{C}_{5} \mathrm{H}_{3}\left(\mathrm{PPh}_{2}\right)\left(\mathrm{CH}_{2} \mathrm{SR}\right)\right]$ (1-R, $\mathrm{R}=\mathrm{Et}, t \mathrm{Bu}, \mathrm{Ph})$, which will be abbreviated as $(\mathrm{P}, \mathrm{SR})$, to complex $[\operatorname{Ir}(\mathrm{COD}) \mathrm{Cl}]_{2}$ [i.e. 1 equiv of $(\mathrm{P}, \mathrm{SR})$ to $\mathrm{Ir}]$ causes the splitting of the chloride-bridged dinuclear structure of the iridium precursor and formation of mononuclear products, according to the stoichiometry of Equation 1.

\section{$<$ Equation 1>}

The products 2-R have been characterized by analytical and spectroscopic $\left({ }^{1} \mathrm{H},{ }^{31} \mathrm{P},{ }^{13} \mathrm{C}\right.$ NMR) methods. The NMR properties are shown in Table 1. These are spectra recorded on solutions obtained upon redissolving the isolated crystals, but correspond to complex equilibria between different species, as will be discussed in detail after the description of the structures. The three compounds show grossly similar physical (color, solubility) and spectroscopic properties in solution, but have different structures in the solid state. Whereas 2-Et and 2-Ph proved to be 5-coordinated with a $\kappa^{2}-P, S$ coordination mode for the bidentate ligand, their 2-tBu analogue is only 4-coordinated, with a $\kappa^{1}-P$ coordination mode and a dangling thioether functionality (see X-ray structures below).

Another remarkable feature has been observed during the crystallization of the crude product obtained from the reaction of $\mathbf{1 - P h}$ and $[\operatorname{Ir}(\mathrm{COD}) \mathrm{Cl}]_{2}(2: 1$ ratio). Whereas crystals of 2-Ph were obtained from dichloromethane/hexane, when the same procedure was followed 
for a toluene/hexane, crystals of a different compound, namely [ $\operatorname{Ir}(\mathrm{COD})$ $(\mathrm{P}, \mathrm{SPh})]\left[\operatorname{Ir}(\mathrm{COD}) \mathrm{Cl}_{2}\right], \mathbf{3 - P h}$, were produced. In fact, a $\mathrm{CDCl}_{3}$ solution of $\mathbf{3 - P h}$ gave a ${ }^{31} \mathrm{P}$ resonance at $9.1 \mathrm{ppm}$, quite different from the value observed for 2-Ph (-3.1). As will be shown later, this resonance results from an equilibrium mixture of $\mathbf{2}-\mathbf{P h}$ and $\mathbf{3 - P h}$. When the synthesis was repeated for a 1:1 ratio of $\mathbf{1 - P h}$ and $[\operatorname{Ir}(\mathrm{COD}) \mathrm{Cl}]_{2}(\mathbf{1}-\mathbf{P h} / \mathrm{Ir}=2)$, the resulting orange solid displayed solution state NMR properties in close correspondence with those of the isolated crystals of 3-Ph. However, this solid also yielded crystals of 2-Ph when recrystallized from dichloromethane/hexane. It seems therefore that the choice of crystallization solvent dictates the nature of the isolated product, indicating a possible equilibrium between 2-Ph and 3-Ph (Equation 2). A more detailed study of this equilibrium will be described below.

$<$ Equation $2>$

(b) X-ray structures.

Views of the molecular geometries of compounds 2-Et, 2-tBu and 2-Ph are presented in Figure 1. It is immediately evident that the Et and $\mathrm{Ph}$ derivatives are 5-coordinated since the $\mathrm{S}$ atoms are within reasonable bonding distances from the $\mathrm{Ir}$ centers (2.3928(17) $\AA$ and $2.3835(12) \AA$, respectively), whereas the $t \mathrm{Bu}$ derivative is only 4-coordinated (the $\mathrm{S} \cdots \mathrm{Ir}$ distance is $5.13 \AA$ ). A comparable Ir-S bonding distances (2.3594(15) $\AA$ ) has been reported for a $[(\mathrm{COD}) \operatorname{Ir}(\mathrm{P}, \mathrm{S} t \mathrm{Bu})]^{+}$complex containing a chiral phosphinite-thioether donor. ${ }^{[57]}$ Other significant bonding parameters are shown in Table 2 for the 5-coordinate compounds and in Table 3 for the 4-coordinate one. When considering the coordination sites as corresponding to the midpoints of the COD C-C double bonds, the geometry of 2-tBu corresponds quite 
closely to an ideal square plane, the Ir atom being only 0.0206(2) $\AA$ away from the leastsquares coordination plane. The coordination geometries of compounds 2-Et and 2-Ph, on the other hand, may be best viewed as intermediate between a distorted trigonal bipyramid and a distorted square pyramid. In the distorted trigonal bipyramidal view, the center of one $\mathrm{C}=\mathrm{C}$ donor function of the $\mathrm{COD}$ ligand $(\mathrm{CO} 2)$ and the $\mathrm{S} 1$ donor atom define the axial positions (angles of 168.1(4) and $166.703(18)^{\circ}$, respectively). However, the equatorial angles deviate severely from the ideal $120^{\circ}$ value, for instance the CT01-Ir(1)-P(1) angle in the two compounds is $153.2(4)$ and $156.06(2)^{\circ}$, respectively, whereas the $\mathrm{P}(1)-\operatorname{Ir}(1)-\mathrm{Cl}(1)$ angle is 91.33(7) and 90.03(3). In the alternative distorted square pyramidal view, the axial ligand would be the $\mathrm{Cl}(1)$ ligand, although a few of the $\mathrm{Cl}(1)$-Ir-X angles $(\mathrm{X}=\mathrm{P}(1), \mathrm{S}(1), \mathrm{CO} 1$ and $\mathrm{CO} 2$ ) are relatively close to $90^{\circ}$. It is interesting to note that in both $\mathbf{2 - \mathbf { E t }}$ and $\mathbf{2 - \mathbf { P h }}$, the $\mathrm{Ir}$ is located off the basal square plane by $0.363(8) \AA$ and $0.3506(3) \AA$ respectively, moreover the Ir is displaced toward the $\mathrm{Cl}$ atom. The distance from $\mathrm{Cl}$ to the square plane is $2.875(6) \AA$ and 2.850(2) A respectively. In fact, it would seem possible to view the structure as derived from that of the corresponding square planar $[\operatorname{Ir}(\mathrm{COD})(\mathrm{P}, \mathrm{SR})]^{+}$by addition of $\mathrm{Cl}^{-}$, resulting in a minimal perturbation of the square planar geometry. Structures of 5-coordinate $\operatorname{IrX}(\mathrm{COD}) \mathrm{L}_{2}$ $(\mathrm{X}=$ any halogen $)$ are not uncommon. They comprise examples with $\mathrm{L}_{2}=$ diphosphines ${ }^{[43,44]}$ including a ferrocenyl functionalized diphosphine, ${ }^{[45]}$ diimines, ${ }^{[46,47]}$ and also with $\mathrm{L}=$ monodentate phosphine. ${ }^{[58]}$ The compounds reported here are the first such examples containing a bidentate P,S-type framework. More importantly, they illustrate the delicate control exerted by the ligand structure on the coordination geometry. This control is unlikely to have an electronic origin, since the Et and $t \mathrm{Bu}$ substituents impart analogous electronic effects, and different from those of the Ph substituent. A steric effect appears more likely, since the $t \mathrm{Bu}$ group is more encumbering than either the $\mathrm{Et}$ or the $\mathrm{Ph}$ group and thus prevents the compound to attain the 5-coordinate geometry. 
$<$ Figure 1 $>$

The $\mathrm{S}$ coordination step is interesting from the stereochemical point of view. Coordination renders the $\mathrm{S}$ atom and the Ir atom asymmetric. In combination with the planar chirality of the substituted ferrocene moiety, eight possible stereoisomers, namly four diastereomeric pairs of enantiomers, can be obtained. There is, however, no indication from the NMR spectrum for the formation of more than one compound. Either the diastereoisomers have significantly different energies such that only one is present at equilibrium, or the isomerization proceeds through a low energy barrier (for instance by decoordination and recoordination through a 4-coordinate square planar intermediate), or finally there may be a combination of both effects. Other observations, shown below, indicate that these compounds undergo dynamic rearrangements very rapidly. In the solid state, compounds 2-Et and 2-Ph show the S atom with the same configuration relative to the ferrocene unit ( $\mathrm{R}$ group exo, lone pair endo and parallel to the $\mathrm{Cp}-\mathrm{Fe}$ axis), and the $\mathrm{Cl}$ ligand is located on the same side (exo) relative to the ferrocene group. The $\mathrm{Ir}-\mathrm{Cl}$ distances of 2.5739(19) and 2.5576(12) $\AA$ compare with those in other 5-coordinate $\operatorname{IrCl}(\mathrm{COD}) \mathrm{L}_{2}$ derivatives with chelating ligands, for instance $2.549 \AA$ in $\operatorname{IrCl}(\mathrm{COD}) \mathrm{L}_{2}\left(\mathrm{~L}_{2}=(2 \mathrm{R}, 3 \mathrm{R})-2,3-\mathrm{O}-\right.$ Isopropylidene-1,4-bis(5H-dibenzophosphol-5-yl)-2,3-butanediol), ${ }^{[43]}$ and $2.585(3) \quad \AA$ in $\operatorname{IrCl}(\mathrm{COD})(\mathrm{dppp}) .{ }^{[44]}$ However, these distances are longer relative to neutral 4-coordinate complexes (e.g. 2.363(1) $\AA$ in $\operatorname{Ir}(\mathrm{COD})\left[=\mathrm{C}\left(\mathrm{NCH}_{2}-p-\mathrm{Tol}\right)_{2} \mathrm{C}_{2} \mathrm{H}_{2}\right] \mathrm{Cl},{ }^{[59]}$ and $2.3625(8) \AA$ in complex 2-tBu). A lengthening of ca. $0.2 \AA$ accompanies this coordination number increase. This observation gives credence to the hypothesis that the $\mathrm{Ir}-\mathrm{Cl}$ bond in the 5-coordinate complexes is highly polarized, especially when comparing it with the insignificant change of the Ir-P distance $[2.3322(15) \AA$ and $2.3289(13) \AA$ in 5-coordinate 2-Et and 2-Ph, respectively; 2.3312(9) $\AA$ in 4-coordinate 2 -t $\mathbf{B u}$ ] and Ir-CT distances [CT = center of the 
COD C=C bond; averages are 2.028(8) $\AA$ for 2-Et, 2.032(10) $\AA$ for 2-Ph and 2.04(4) $\AA$ for 2-

$t \mathrm{Bu}]$.

The structure of compound 3-Ph contains discrete square planar $\left[\operatorname{Ir}(\mathrm{COD})\left(\kappa^{2}-\mathrm{P}, \mathrm{SPh}\right)\right]^{+}$ and $\left[\operatorname{Ir}(\mathrm{COD}) \mathrm{Cl}_{2}\right]^{-}$anions. An interstitial toluene molecule completes the crystal packing. One $\mathrm{H}$ atom of a $\mathrm{CH}_{2}$ group of the COD ligand in the cation is located at a relatively short intermolecular contact $(2.759 \AA)$ above the Ir atom in the anion, see Figure 2, a location which places it in an approximately ideal axial position. Indentification of such an interaction in solution by NMR spectroscopy was precluded by the complex redistribution equilibria (see below). However, the Ir atom in each ion sits very close to the ideal square place defined by the middle of the $\mathrm{C}=\mathrm{C}$ bonds and the $\mathrm{P}, \mathrm{S}$ or $\mathrm{Cl}$ donors, respectively $(0.0158(5) \AA$ in the cation, $0.0066(5) \AA$ in the anion). Structures of 4-coordinate cationic complexes of type $\left[\operatorname{Ir}(\mathrm{COD}) \mathrm{L}_{2}\right]^{+}$are quite common in the literature with various types of bidentate $\mathrm{L}_{2}$ and monodentate L ligands, including two precedents with a chelating P,S-type ligand, $\mathrm{Ph}_{2} \mathrm{PO}\left(1,2-\right.$ cyclo- $\left.\mathrm{C}_{6} \mathrm{H}_{10}\right) \mathrm{S} t \mathrm{Bu}$ and $\mathrm{Ph}_{2} \mathrm{PCH}_{2} \mathrm{P}(t \mathrm{Bu})_{2} \mathrm{~S} .^{[57,60]}$ All these previously reported salts contain $\mathrm{BF}_{4}^{-}, \mathrm{PF}_{6}^{-}, \mathrm{SbF}_{6}^{-}, \mathrm{CF}_{3} \mathrm{SO}_{3}^{-}$, or tetraarylborates as counterions. None contains the $\left[\operatorname{Ir}(\mathrm{COD}) \mathrm{Cl}_{2}\right]^{-}$anion. In fact, this quite simple anion does not appear to have previously been crystallographically characterized. This situation differs considerably from that of the rhodium congeners, for which several structure of salts of type $\left[\mathrm{Rh}(\mathrm{COD}) \mathrm{L}_{2}\right]\left[\mathrm{Rh}(\mathrm{COD}) \mathrm{Cl}_{2}\right]$ have been reported. ${ }^{[61-65]}$

$<$ Figure 2>

Selected bonding parameters for compounds $\mathbf{3 - P h}$ are shown in Table 4. Both ions exhibit a relatively undistorted square planar geometry when considering the center of the $\mathrm{COD} \mathrm{C}=\mathrm{C}$ bonds $(\mathrm{CT})$ as defining the coordination positions. The Ir-CT distances are 
significantly shorter in the anion (average 1.976(5) $\AA$ ) than in the cation (average 2.09(4) $\AA$ ), and the latter are marginally longer than in the 4 - and 5-coordinate neutral complexes 2-R discussed above, attesting to the importance of back-bonding for the Ir-COD interaction. The Ir-P and Ir-S bond lengths in the cation are shorter than those in the neutral complexes, irrespective of their coordination number. This effect can be attributed to the metal ion contraction on going from the neutral to the charged system, because of an increase of effective nuclear charge, and agrees with a predominant $\sigma$-bonding component for the Ir-P and Ir-S interactions.

\section{(c) NMR spectroscopy of compounds 2-R}

Given the subtle structural difference observed for compounds $\mathbf{2}$ in the solid state depending on $\mathrm{R}$, one might wonder whether the same structural dichotomy is maintained in solution. A detailed analysis of the NMR properties seems to suggest that this is the case. The ${ }^{31} \mathrm{P}$ resonance chemical shift is essentially identical for compounds $\mathbf{2 - E t}$ and $\mathbf{2}$-Ph, while

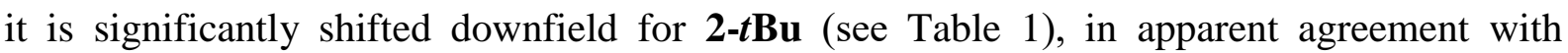
donation from the phosphorus atom to a less electron rich metal in the latter case. This observation is the strongest indication in favor of a similar structure in the solid state and in chloroform solution for compounds 2 . Given the planar chirality of the functionalized Cp ring of the ferrocene moiety, all COD proton and carbon nuclei are magnetically inequivalent in both types of structure, although a higher degree of inequivalence could be expected for the 5-coordinate structures where there is coordination-induced chirality at both the S and Ir atoms. The NMR spectra are however deceptively simple since only two sets of ${ }^{13} \mathrm{C}$ resonances are observed for both the $\mathrm{CH}$ and the $\mathrm{CH}_{2}$ nuclei for all three compounds. For compound 2-tBu, the $C \mathrm{H}$ resonances could not be identified, even by an ${ }^{1} \mathrm{H}^{-13} \mathrm{C}$ HMQC 
experiment at temperatures down to $213 \mathrm{~K}$. On the other hand, these peaks were visible when the spectrum was recorded in toluene- $d_{8}$ solution (see Experimental Part). The pairs of $\mathrm{C}$ atoms with distinct chemical shifts are probably associated to the different coordination positions (i.e. trans to $\mathrm{P}$ and trans to $\mathrm{S} / \mathrm{Cl}$ ), whereas the asymmetry above and below the square coordination plane has a negligible effect on the chemical shift. Only for the ${ }^{1} \mathrm{H} \mathrm{CH}$ (COD) resonances in compound 2-Et was a slight asymmetry detected in the corresponding NMR spectra due to this asymmetry. This observation alone is not sufficient to confirm the difference in coordination geometry within the three compounds. However, the chemical shifts of the $\mathrm{CH}(\mathrm{COD}){ }^{1} \mathrm{H}$ and ${ }^{13} \mathrm{C}$ resonances change significantly on going from 2-Et and 2Ph. In particular, the $\mathrm{CH}$ resonances in the ${ }^{1} \mathrm{H}$ NMR spectrum proved to be more spread apart in $2-t \mathbf{B u}$, while one of the two $\mathrm{CH}$ resonances in the corresponding ${ }^{13} \mathrm{C}$ NMR spectrum is upfield shifted by ca. $15 \mathrm{ppm}$ relative to the same resonance in the other two compounds. The chemical shift of the single ${ }^{1} \mathrm{H}$ resonance of the unsubstituted $\mathrm{Cp}$ ligand is also significantly different for $\mathbf{2}-\mathbf{t} \mathbf{B u}$ relative to the other two compounds, and a slight difference is even observable for the ${ }^{13} \mathrm{C}$ resonance of the same group. The ${ }^{1} \mathrm{H}$ and ${ }^{13} \mathrm{C}$ resonances of the $\mathrm{CH}_{2}$ group linking the $\mathrm{S}$ donor to the ferrocene unit, on the other hand, seem sensitive to the electronic nature of the SR group, since they are similar for the Et and $t \mathrm{Bu}$ derivatives and different for the $\mathrm{Ph}$ derivative. In conclusion, the overall NMR behaviour suggests that the solution structures of compounds $\mathbf{2}$ may be identical to those observed in the solid state.

\section{(d) Study of solution equilibria.}

Solutions obtained by mixing complexes $[\operatorname{Ir}(\mathrm{COD}) \mathrm{Cl}]_{2}$ and the free ligand $\mathbf{1 - P h}$ in various ratios were investigated by ${ }^{1} \mathrm{H}$ and ${ }^{31} \mathrm{P}$ NMR spectroscopy. Only one set of resonances was observed for all ratios up to $\mathbf{1 - P h} / \mathrm{Ir}=1: 1$, but several individual resonances of this set (notably the ${ }^{31} \mathrm{P}$ resonance and the ${ }^{1} \mathrm{H}$ resonances of the ferrocene unsubstituted $\mathrm{Cp}$, 
of one of the substituted $\mathrm{Cp}$ protons, and of the two $\mathrm{CH}_{2}$ protons) exhibited a continuous variation of the chemical shift as a function of the 1-Ph/Ir ratio (see Figure 3). The COD resonances were too broad to allow their accurate monitoring. For 1-Ph/Ir ratios greater than 1, the resonances of the free ligand 1-Ph (mostly evident from the ${ }^{31} \mathrm{P}$ NMR spectrum) also appeared.

\section{$<$ Figure $3>$}

The behaviour illustrated in Figure 3 can be rationalized on the basis of Scheme 1 where rapid site exchange between the species participating in the equilibrium is required. A similar equilibrium has previously been proposed for an analogous system with the hemilabile N,O ligand 1-(2'-pyridyl)-3-dimethylamino-2-propen-1-one. ${ }^{[64]}$ The resonances did not decoalesce into those of the individual species upon cooling to $213 \mathrm{~K}$ for a solution containing a 1-Ph/Ir ratio of 0.6. The first ligand-metal equilibrium leading to 3-Ph must be essentially quantitative, because the NMR signals of free 1-Ph appear immediately after consumption of one equivalent of the ligand per Ir dimer, while they are not visible before this ratio is attained.

$<$ Scheme 1>

Under the assumption of a first quantitative addition of 1-Ph to $[\operatorname{Ir}(\mathrm{COD}) \mathrm{Cl}]_{2}$, the individual concentrations of 2-Ph and 3-Ph for each measured solution were obtained from the equilibrium expression (Equation $3, \mathrm{R}=\mathrm{Ph}$ ), using $\mathrm{K}$ as an adjustable parameter. These concentrations were then used to calculate, for each resonance, the chemical shifts according to Equation $4(\mathrm{R}=\mathrm{Ph})$. Fitting to the experimental data yielded a reasonable agreement, using the same value of the equilibrium constant (0.008) for all resonances, as shown in 
Figure 3. The full fitting procedure and the values of $\delta_{2}$-Ph and $\delta 3$-Ph for each resonance, as obtained from the fittings, are given in the Supporting Information.

\section{$<$ Equation 3 and Equation $4>$}

When a sample of 1-Et was added to $[\operatorname{Ir}(\mathrm{COD}) \mathrm{Cl}]_{2}$ in a 1:1 molar ratio in $\mathrm{CDCl}_{3}$ (i.e. a 1-Et/Ir ratio of 0.5 ), a single ${ }^{31} \mathrm{P}$ NMR resonance was observed at $\delta 10.9$. The isolated complex 2-Et (having a 1-Et/Ir ratio of 1), on the other hand, yielded a ${ }^{31} \mathrm{P}$ resonance at $\delta-4.2$ under the same conditions (see Table 1), whereas the resonance of the free ligand 1-Et is at 20. Addition of an excess of ligand 1-Et shifted this resonance further to $\delta-4.6$. We therefore presume that the solution behaviour of " $\operatorname{Ir}(\mathrm{COD}) \mathrm{Cl}$ " in the presence of 1-Et is the same as with the 1-Ph ligand. A more detailed equilibrium study was not carried out in this case. In contrast, treatment of complex $[\operatorname{Ir}(\mathrm{COD}) \mathrm{Cl}]_{2}$ with various amounts of $\mathbf{1 - t} \mathbf{B u}$ in $\mathrm{CDCl}_{3}$ led to the observation of two new ${ }^{31} \mathrm{P}$ NMR resonances. Whereas one of these (at $\delta$ 17.5) exhibited the same chemical shift at all 1-t $\mathbf{B u} / \mathrm{Ir}$ ratios, the other one shifted continuously from ca. $\delta 14.6$ at $\mathbf{1 - t} \mathbf{B u} / \operatorname{Ir}=0.2$ to ca. 15.7 at $\mathbf{1 - t} \mathbf{B u} / \operatorname{Ir}=1$, see Figure 4(a). In addition, the relative intensity of these two resonances changed in favor of the second one upon increasing the 1-t $\mathbf{B u} /$ Ir ratio, until the first one completely disappeared at the point when 1-t $\mathbf{B u} /$ Ir $=$ ca. 1, see Figure 4(b). Further additions of the free ligand no longer moved the $\delta 15.7$ resonance, although, a new resonance due to the excess of free 1- $t \mathbf{B u}$ started to appear at $\delta$-20.0. This observed behaviour suggests the presence of at least three P-containing Ir complexes: two that are in rapid exchange on the NMR time scale, generating the resonance that is shifting in the $\delta 14.6-15.7$ range, and a third one giving the $\delta 17.5$ resonance. The latter species exchanges slowly on the NMR timescale, or not at all, with the other two. In addition, the appearance of the free 1-t $\mathbf{B u}$ resonance immediately after attaining the 1-t $\mathbf{B u} / \mathrm{Ir}$ 
ratio of 1 , suggested an essentially quantitative first addition of $\mathbf{1 - t} \mathbf{B u}$ to $[\operatorname{Ir}(\mathrm{COD}) \mathrm{Cl}]_{2}$ to generate 3-t $\mathbf{B u}$, like for the case of the 1-Ph addition.

$<$ Figure $4>$

It seems logical to assume, on the basis of the results shown above for the 1-Ph/Ir system, that the shifting resonance is due to the rapidly equilibrating mixture of compounds 2$\boldsymbol{t} \mathbf{B u}$ and the salt $\left[\operatorname{Ir}(\mathrm{COD})\left(\kappa^{2}-\mathrm{P}, \mathrm{St} \mathrm{Bu}\right)\right]^{+}\left[\operatorname{Ir}(\mathrm{COD}) \mathrm{Cl}_{2}\right]^{-}, \mathbf{3 - t} \mathbf{B u}$ (equilibrium of Equation 2). The chemical shift observed at low 1-t $\mathbf{B u}$ /Ir ratio (Figure 4(a), ca. $\delta 14.5$ ) is close to that observed at low 1-Ph/Ir ratio (Figure 3, ca. $\delta 11$ ) and attributed to compound 3-Ph. For the 1-Ph/Ir system, addition of the free ligand leads to an upfield shift toward the resonance of 5coordinate 2-Ph (ca. $\delta-3$ ), whereas for the 1-t $\mathbf{B u} /$ Ir system, addition of the free ligand leads to a downfield shift toward the resonance of 4-coordinate $\mathbf{2 - t} \mathbf{B u}$ (ca. $\delta$ 15.5). This proposition is in agreement with the observed behaviour of the same system in $\mathrm{C}_{6} \mathrm{D}_{6}$ : the lower polarity of this solvent is expected to disfavor formation of the ionic system and, indeed, the resonance does not shift significantly by varying the $\mathbf{1 - t} \mathbf{B u} /$ Ir ratio in the 0 to $>1$ range ( $\delta$ always in the $15.68-15.71$ range).

We now need to assign the $\delta 17.5$ resonance and to rationalize the fact that it is observed only for the 1-t $\mathbf{B u} /$ Ir system. The most reasonable proposal that we are able to advance involves a neutral dinuclear complex with a bridging $\mathrm{P}, \mathrm{S} t \mathrm{Bu}$ ligand (4-t $\mathbf{B u})$, see Scheme 2. Precedents for this type of structural arrangement exist for P,N ligands. ${ }^{[66,67]}$ Since the equilibrium between the 5-coordinate and the 4-coordinate isomers of 2-R lies strongly in favor of the latter when $\mathrm{R}=t \mathrm{Bu}$, the pendant $\mathrm{S} t \mathrm{Bu}$ arm is available to coordinate the Ir center in the unsaturated $\operatorname{Ir}(\mathrm{COD}) \mathrm{Cl}$ complex, which is in equilibrium with the dichlorobridged dimer. It is rather remarkable, however, that this process is slower than the addition 
of the chloride anion to the same position. We presume that this is so for steric reasons. The reversible association/dissociation process of the pendant $\mathrm{St} \mathrm{Bu}$ arm leading from 2-t $\mathbf{B u}$ to 3$\boldsymbol{t} \mathbf{B u}$ is fast because it is intramolecular. The reason why analogous compounds $\mathbf{4 - P h}$ and $\mathbf{4 - E t}$ are not observed would then be related to the preferred sulfur coordination to the same $\mathrm{Ir}$ center, in the 5-coordinate geometry of 2-Ph and 2-Et.

\section{$<$ Scheme $2>$}

According to this proposal, compound $\mathbf{4}$ has an identical stoichiometry to compound $\mathbf{3}$. Therefore, the 3-t $\mathbf{B u} / \mathbf{4}-\mathbf{t} \mathbf{B u}$ ratio should be independent on the 1-t $\mathbf{B u} /$ Ir ratio. This ratio can be estimated from the extrapolated relative intensities of the $\delta 14.6$ and 17.5 peaks as 1-t $\mathbf{B u} / \mathrm{Ir}$ $\rightarrow 0$ (ca. 42.3:57.7), from (Figure 4(b). This number can in turn be used to estimate the individual concentrations of $\mathbf{2 - t} \mathbf{B u}$ and $3-t \mathbf{B u}$ at each $\mathbf{1 - t} \mathbf{B u} / \mathrm{Ir}$ ratio. At this point, the concentration of each iridium-containing species can be calculated solving the equilibrium relationship (Equation 3, $\mathrm{R}=t \mathrm{Bu}$ ), using $K$ as an adjustable parameter. These concentrations were then used to calculate the ${ }^{31} \mathrm{P}$ chemical shift according to Equation $4(\mathrm{R}=t \mathrm{Bu})$. Fitting of the simulated and experimental data yielded a reasonable agreement for an equilibrium constant of 0.036 , as shown in Figure 4(a). Thus, $K$ is greater for $\mathrm{R}=t \mathrm{Bu}(0.036)$ than for $\mathrm{R}$ $=\mathrm{Ph}(0.008)$. The release of steric pressure upon transforming the chelating $\mathrm{P}, \mathrm{S} t \mathrm{Bu}$ ligand into a dangling one (whereas the $\mathrm{P}, \mathrm{SPh}$ ligand remains chelating in compound 2-Ph) may provide an explanation of this difference.

(e) Comparison with Rh coordination chemistry and mixed Rh-Ir studies.

When samples of 1-R $(\mathrm{R}=\mathrm{Ph}, \mathrm{Et}, t \mathrm{Bu})$ were reacted with $[\mathrm{Rh}(\mathrm{COD}) \mathrm{Cl}]_{2}$ in a 2:1 molar ratio, a single ${ }^{31} \mathrm{P}$ resonance, split into a doublet by a rhodium coupling, was observed in each 
case in the NMR spectrum. This resonance is therefore assigned to a product with the stoichiometry $\mathrm{RhCl}(\mathrm{COD})(\mathrm{P}, \mathrm{SR})(\mathbf{5}-\mathbf{R})$ see Table 5. The very similar values of the chemical shifts and coupling constants, in contrast to the behaviour observed for the Ir complexes, strongly indicates the same coordination mode for the three ligands with respect to $\mathrm{Rh}(\mathrm{I})$.

When a sample of 1-Ph in $\mathrm{CDCl}_{3}$ was reacted with $[\mathrm{Rh}(\mathrm{COD}) \mathrm{Cl}]_{2}$ in a 1:1 molar ratio, a doublet resonance was observed at $24 \mathrm{ppm}(143 \mathrm{~Hz})$ in the ${ }^{31} \mathrm{P}$ NMR spectrum. Both the chemical shift and the coupling constant of this resonance are very close, but not identical, to those obtained using a 2:1 ratio. Therefore, we presume that the compound formed under these conditions (6-Ph) has the same structure as the iridium analogue $\mathbf{3 - P h}$, namely $[\mathrm{Rh}(\mathrm{COD})(\mathrm{P}, \mathrm{SPh})]\left[\mathrm{Rh}(\mathrm{COD}) \mathrm{Cl}_{2}\right]$. As for compounds 5-R, there are two possibilities: an ionic structure $[\mathrm{Rh}(\mathrm{COD})(\mathrm{P}, \mathrm{SR})]^{+} \mathrm{Cl}^{-}$, and a neutral structure with a dangling thioether function, $\mathrm{RhCl}(\mathrm{COD})\left(\kappa^{1}-\mathrm{P}, \mathrm{SR}\right)$, as seen for the iridium analogue $\mathbf{2}-\mathbf{t} \mathbf{B u}$. In both cases, the rhodium complexes are consistently 4-coordinated, in agreement with the lower propensity of $\mathrm{Rh}(\mathrm{I})$, relative to $\operatorname{Ir}(\mathrm{I})$, to give 5-coordinate geometries with the involvement of the $\mathrm{d}_{\mathrm{z} 2}$ orbital. A few examples of 4-coordinate $\left[\mathrm{Rh}(\mathrm{COD}) \mathrm{L}_{2}\right]^{+}$complexes having $\mathrm{Cl}^{-}$as the counter ion have been characterized by X-ray crystallography, namely $\left[\mathrm{Rh}(\mathrm{COD})(\text { bipy })_{2}\right]^{+},{ }^{[49]}\left[\mathrm{Rh}(\mathrm{COD}) \mathrm{L}_{2}\right]^{+}$ $(\mathrm{L}=1,3$-dimethylimidazoline-2-ylidene $),{ }^{[50]}$ and a chelated version of the latter $\left[\mathrm{L}_{2}=\right.$ $\left(\mathrm{MeNC}_{3} \mathrm{H}_{2} \mathrm{~N}-\left(\mathrm{CH}_{2}\right)_{3}-\mathrm{NC}_{3} \mathrm{H}_{2} \mathrm{NMe}\right] .{ }^{[51]}$ However, addition of the 1-R ligands to $[\mathrm{Rh}(\mathrm{COD}) \mathrm{Cl}]_{2}$ in $\mathrm{C}_{6} \mathrm{D}_{6}$ generated soluble products whose ${ }^{31} \mathrm{P}$ NMR resonances [5-Et: $21.8(147 \mathrm{~Hz})$; 5-tBu: $23.6(148 \mathrm{~Hz})$; 5-Ph: $21.6(148 \mathrm{~Hz})]$ turned out to be essentially identical to those recorded in $\mathrm{CDCl}_{3}$. This result strongly suggests that the adducts are neutral. In conclusion, the $\operatorname{Ir}(\mathrm{I})$ center has a greater tendency to coordinate both the thioether function and the $\mathrm{Cl}^{-}$ion. The latter, however, is rather weakly coordinated as shown by the long $\mathrm{Ir}-\mathrm{Cl}$ distances in the $\mathrm{X}$-ray structures (vide supra). 
Subsequent mixing experiments were carried out in order to probe the relative stability of $\mathrm{Rh}(\mathrm{I})$ and $\operatorname{Ir}(\mathrm{I})$ complexes with the coordinated P,SR ligands. The addition of $[\operatorname{Ir}(\mathrm{COD}) \mathrm{Cl}]_{2}$ to a sample of $\mathbf{5 - P h}$ in a $1: 2$ molar ratio made the ${ }^{31} \mathrm{P}$ NMR resonance of the starting $\mathrm{Rh}$ complex and the $\mathrm{P}-\mathrm{Rh}$ coupling disappear, yielding a new resonance (singlet) at $\delta$ -0.25. From the observed chemical shift ( $c f$. Table 5) and the absence of Rh coupling, we propose that the reaction leads to complex 2-Ph, according to Equation 5. The same ${ }^{31} \mathrm{P}$ NMR resonance $(\delta-0.21)$ was obtained by adding $1 / 2$ mol of $[\operatorname{Ir}(\mathrm{COD}) \mathrm{Cl}]_{2}$ and $1 / 2 \mathrm{~mol}$ of $[\mathrm{Rh}(\mathrm{COD}) \mathrm{Cl}]_{2}$ simultaneously to one mol of 1-Ph. However, complex $\mathbf{2 - P h}$ cannot be the only species in solution, because its resonance is shifted relative to that assigned to pure $\mathbf{2}-\mathbf{P h}$. From the observed NMR behaviour of complex 2-Ph in the presence of variable amounts of $[\operatorname{Ir}(\mathrm{COD}) \mathrm{Cl}]_{2}$ (see Figure 3 and related discussion above), we can presume that the reaction mixture also contains equilibrium amounts of complex $\left[\operatorname{Ir}(\mathrm{COD})\left(\kappa^{2}-\mathrm{P}, \mathrm{SPh}\right)\right]\left[\mathrm{Rh}(\mathrm{COD}) \mathrm{Cl}_{2}\right]$, 3', obtained by transfer of the chloride ligand to the dinuclear rhodium complex as shown in Equation 6.

$<$ Equation 5 and Equation 6>

It is interesting to remark that the resonance observed for this mixture (ca. $-0.2 \mathrm{ppm}$ ), which contains a $\mathrm{P}, \mathrm{SPh}:(\mathrm{Rh}+\mathrm{Ir})$ ratio of 0.5 , is much closer to the resonance of $\mathbf{2}-\mathbf{P h}$ than that of a solution with the same $\mathrm{P}, \mathrm{SPh}$ to metal ratio, but containing only Ir (ca. 8 ppm, see Figure 3). This observation shows that $[\operatorname{Ir}(\mathrm{COD}) \mathrm{Cl}]_{2}$ is a stronger chloride scavenger than its rhodium analogue. Another obvious conclusion of this study is that the iridium ion forms stronger bonds with the phosphorus and sulphur atoms of the P,SPh ligand than does the rhodium ion. 


\section{(f) Catalytic studies.}

Complexes 2 were tested as catalyst for the hydrogenation of diphenylacetylene. The results are presented in Table 6. Under 30 bars of dihydrogen pressure at room temperature with $1 \mathrm{~mol} \%$ of precatalyst, compound $\mathbf{2 - t} \mathbf{B u}$ gave a quantitative conversion after $6 \mathrm{~h}$, whereas complex 2-Ph was less active, yielding only a 59\% conversion. In both cases, significant amounts of 1,2-diphenylethane were detected by GC (alkenes/alkane ratio = 92/8 for $\mathbf{2 - P h}$ and 78/22 for $\mathbf{2}-\mathbf{t} \mathbf{B u})$. Compared to other hydrogenation systems for the selective transformation of alkynes into alkenes, these systems perform rather poorly. ${ }^{[68-75]}$

Furthermore, the stereoselectivity of the reaction, especially with compound $\mathbf{2 - t} \mathbf{B u}$, is also quite poor (cis-stilbene/ trans-stilbene ratio ratio $=91 / 9$ for $\mathbf{2}-\mathbf{P h}$ and $82 / 18$ for $\mathbf{2}$-t $\mathbf{B u}$ ). The presence of E-alkenes after hydrogenation of alkynes is commonly explained by the isomerisation of Z-alkenes, which are the primary products arising from the syn-addition of $\mathrm{H}_{2}$ to the C-C triple bonds. ${ }^{[76-78]}$ In order to determine whether similar reasons are involved in our system, we carried out the reaction of $c i s$-stilbene with dihydrogen in presence of complexes 2-Ph or 2-tBu under the same conditions described in Table 6 for diphenylacetylene. Isomerisation to trans-stilbene as well as hydrogenation to 1,2-diphenylethane did occur, although the rate of this transformation was slower than the direct formation of these two products from diphenylacetylene. This result suggests that the isomerization and further hydrogenation processes probably occur mostly from the vinyl intermediate, before the primary cis-stilbene product is formed by reductive elimination. However, recoordination of the $c i s$-stilbene followed by both isomerization and further hydrogenation are also possible.

\section{Conclusion}


Use of the ferrocenyl phosphine-thioether ligands $\mathbf{1 - R}(\mathrm{R}=\mathrm{Et}, \mathrm{Ph}, t \mathrm{Bu})$ has allowed to reveal that the coordination geometry of chlorocyclooctadieneiridium(I) ligand adducts, both in the solid state and in solution, is delicately controlled by the nature of the R substituent, yielding 5-coordinated complexes $\mathbf{2}-\mathrm{R}$ for $\mathrm{R}=\mathrm{Et}$, $\mathrm{Ph}$ and a 4-coordinate one for $\mathrm{R}=t \mathrm{Bu}$, the latter featuring a dangling thioether group. The ligand chirality controls the geometry at the sulfur and iridium atoms, producing single diastereomers.

The solid state geometries appear to be maintained in solution. However, complex equilibria between various structures are established. The chloride ligand is loosely bound to iridium in the 5 -coordinate complexes $\mathbf{2}-\mathbf{R}$, leading to its scavenging by excess metal complex and to a rapid equilibration between complexes $\mathbf{2 - R}$ and ionic $\left[\operatorname{Ir}(\mathrm{COD})\left(\kappa^{2}-\right.\right.$ P,SR $)]^{+}\left[\operatorname{Ir}(\mathrm{COD}) \mathrm{Cl}_{2}\right]^{-}$3-R. Salt-like compounds of type $\left[\operatorname{Ir}(\mathrm{COD})\left(\mathrm{k}^{2}-\mathrm{L}^{-L^{\prime}}\right)\right]\left[\operatorname{Ir}(\mathrm{COD}) \mathrm{X}_{2}\right]^{-}$ have not been structurally characterized previously for any L-L' or X, though they are quite common for the $\mathrm{Rh}$ congener. Furthermore, competitive coordination reactions between rhodium and iridium for ligand 1-Ph lead only to iridium coordination, probing the greater affinity of P,SR ligands for the heavier metal. The same solution is obtained whether the P,SR ligand is initially bonded to Rh or Ir, indicating a high lability for such systems.

Complexes 2-R catalyse the hydrogenation of diphenylacetylene at room temperature, paving the way to the application of such complexes to other hydrogenation reactions. Our particular attention is devoted to asymmetric hydrogenation, taking advantage of the availability of the chiral ligands $\mathbf{1 - R}$ in optically pure form. Further studies in this direction are currently in progress in our laboratories.

\section{Experimental Section}


General. All reactions were carried out under an argon atmosphere using standard Schlenk techniques. Solvents were carefully dried by conventional methods and distilled under argon before use. The (R/S)-2-diphenylphosphino-(R-thiomethyl)ferrocene ligands (1$\mathbf{R}, \mathrm{R}=\mathrm{Et}, t \mathrm{Bu}, \mathrm{Ph})$ were prepared according to a published procedure ${ }^{[56]}$ from racemic 2(diphenylthiophosphinoferrocenyl)methanol. ${ }^{[79]}$ NMR spectra were recorded on Bruker AC200 and Bruker Avance 500 FT-NMR spectrometers. The resonances were calibrated relative to the residual solvent peaks and are reported with positive values downfield from TMS. The NMR spectra of the new compounds $2-\mathbf{R}(\mathrm{R}=\mathrm{Et}, t \mathrm{Bu}, \mathrm{Ph})$ are collected in Table 1.

Synthesis of IrCl(COD)(P,SEt), 2-Et. In a Schlenk tube, under argon, ligand 1-Et (69 $\mathrm{mg}, 0.155 \mathrm{mmol})$ was dissolved in dichloromethane $(3 \mathrm{~mL})$ and $[\operatorname{Ir}(\mathrm{COD}) \mathrm{Cl}]_{2}(52 \mathrm{mg}, 0.077$ mmol) was added. After $1 \mathrm{~h}$ of stirring, the addition of pentane $(10 \mathrm{~mL})$ yielded a yellow precipitate, which was then filtered to give $[\operatorname{IrCl}(\mathrm{COD})(\mathrm{P}, \mathrm{SEt})](104 \mathrm{~g}, 86 \%$ yield). Elem. Anal., $\mathrm{C}_{33} \mathrm{H}_{37} \mathrm{ClFe} I r P S$ (780.21): calcd. C 50.80, H 4.78; found C 50.64, H 5.05.

Synthesis of $\operatorname{IrCl}(\mathbf{C O D})(\mathbf{P}, \mathbf{S t} \mathbf{B u}), 2-t \mathrm{Bu}$. In a Schlenk tube, under nitrogen, ligand 1$\boldsymbol{t}$ Bu $(272 \mathrm{mg}, 0.576 \mathrm{mmol})$ was dissolved in dichloromethane $(3 \mathrm{~mL})$ and $[\operatorname{Ir}(\mathrm{COD}) \mathrm{Cl}]_{2}(193$ $\mathrm{mg}, 0.288 \mathrm{mmol}$ ) was added. The solution was stirred for $2 \mathrm{~h}$ at room temperature and $10 \mathrm{~mL}$ of hexane was the added to form a yellow precipitate. The precipitate was filtered under nitrogen and washed with hexane, to give $[\operatorname{IrCl}(\mathrm{COD})(\mathrm{P}, \mathrm{St} \mathrm{Bu})](416 \mathrm{mg}, 89 \%$ yield). Elem. Anal., $\mathrm{C}_{35} \mathrm{H}_{41} \mathrm{ClFeIrPS} \cdot \mathrm{CH}_{2} \mathrm{Cl}_{2}$ (893.13): calcd. $\mathrm{C} 48.41, \mathrm{H} 4.85$; found $\mathrm{C} 48.62, \mathrm{H}$ 4.70. The presence of dichloromethane was evident from the NMR spectrum recorded on a solution of the single crystals. ${ }^{1} \mathrm{H}$ NMR $\left(500 \mathrm{MHz}\right.$, toluene- $\left.d_{8}\right): \delta 8.33\left(\mathrm{dd}, 2 \mathrm{H}, \mathrm{Ph}, \mathrm{J}_{\mathrm{HH}}=10 \mathrm{~Hz}\right.$, $\left.\mathrm{J}_{\mathrm{HP}}=12 \mathrm{~Hz}\right) ; 7.38\left(\mathrm{dd}, 2 \mathrm{H}, \mathrm{Ph}, \mathrm{J}_{\mathrm{HH}}=10 \mathrm{~Hz}, \mathrm{~J}_{\mathrm{HP}}=12 \mathrm{~Hz}\right) ; 7.19(\mathrm{~m}, 2 \mathrm{H}, \mathrm{Ph}) ; 7.17(\mathrm{~m}, 1 \mathrm{H}, \mathrm{Ph}) ;$ $6.97(\mathrm{~m}, 2 \mathrm{H}, \mathrm{Ph}) ; 6.95(\mathrm{~m}, 1 \mathrm{H}, \mathrm{Ph}) ; 4.67(\mathrm{~s}, \mathrm{sCp}) ; 4.58\left(\mathrm{~d}, 1 \mathrm{H}, \mathrm{CH}_{2}, \mathrm{~J}_{\mathrm{HH}}=13 \mathrm{~Hz}\right) ; 4.24(\mathrm{~d}, 1 \mathrm{H}$, $\left.\mathrm{CH}_{2}, \mathrm{~J}_{\mathrm{HH}}=13 \mathrm{~Hz}\right) ; 4.18$ (s, sCp); 4.16 (s, 5H, Cp); 4.13 (t, sCp, $\left.\mathrm{J}_{\mathrm{HH}}=2 \mathrm{~Hz}\right) ; 3.88$ (br, COD); 
2.30 (m, COD); 2.08 (m, COD); 1.65 (m, COD); 1.49 (m, COD); 1.44 (s, 9H, tBu). ${ }^{13} \mathrm{C} \mathrm{NMR}$ $\left(500 \mathrm{MHz}\right.$, toluene- $\left.d_{8}\right): \delta 136.05\left(\mathrm{~d}, 2 \mathrm{C}, \mathrm{Ph}, \mathrm{J}_{\mathrm{CP}}=12 \mathrm{~Hz}\right) ; 135.0$ (d, quat $\left.\mathrm{Ph}, \mathrm{J}_{\mathrm{CP}}=50 \mathrm{~Hz}\right)$; $133.70\left(\mathrm{~d}, 2 \mathrm{C}, \mathrm{Ph}, \mathrm{J}_{\mathrm{CP}}=12 \mathrm{~Hz}\right) ; 133.4\left(\mathrm{~d}\right.$, quat $\left.\mathrm{Ph}, \mathrm{J}_{\mathrm{CP}}=50 \mathrm{~Hz}\right) ; 130.00\left(\mathrm{~d}, 1 \mathrm{C}, \mathrm{Ph}, \mathrm{J}_{\mathrm{CP}}=3 \mathrm{~Hz}\right)$; $129.05\left(\mathrm{~d}, 1 \mathrm{C}, \mathrm{Ph}, \mathrm{J}_{\mathrm{CP}}=2 \mathrm{~Hz}\right) ; 127.40\left(\mathrm{~d}, 2 \mathrm{C}, \mathrm{Ph}, \mathrm{J}_{\mathrm{CP}}=6 \mathrm{~Hz}\right) ; 126.95\left(\mathrm{~d}, 2 \mathrm{C}, \mathrm{Ph}, \mathrm{J}_{\mathrm{CP}}=10 \mathrm{~Hz}\right)$; 91.02 (d, quat $\left.\mathrm{Cp}, \mathrm{J}_{\mathrm{CP}}=16 \mathrm{~Hz}\right) ; 74.8$ (d, quat $\left.\mathrm{Cp}, \mathrm{J}_{\mathrm{CP}}=50 \mathrm{~Hz}\right) ; 74.42\left(\mathrm{~d}, 1 \mathrm{C}, \mathrm{sCp}, \mathrm{J}_{\mathrm{CP}}=6 \mathrm{~Hz}\right)$; 71.37 (s, Cp); 71.24 (d, 1C, sCp, J $\left.\mathrm{JP}_{\mathrm{C}}=7.4 \mathrm{~Hz}\right) ; 69.7$ (d, 1C, sCp, $\left.\mathrm{J}_{\mathrm{CP}}=6.5 \mathrm{~Hz}\right) ; 52$ (COD); 43.05 (s, S- $\left.\underline{\mathrm{C}}\left(\mathrm{CH}_{3}\right)\right) ; 30.75$ (COD); 32.72 (COD); 30.7 (s, S-C( $\left.\left.\underline{\mathrm{CH}}_{3}\right)\right) ; 29.1$ (s, $\left.\mathrm{CH}_{2}\right) .{ }^{31} \mathrm{P}$ NMR (500 MHz, toluene- $\left.d_{8}\right): \delta 11.8$.

Synthesis of IrCl(COD)(P,SPh), 2-Ph. In a Schlenk tube, under nitrogen, ligand 1-Ph (240 mg, $0.488 \mathrm{mmol})$ was dissolved in dichloromethane $(4 \mathrm{~mL})$ and solid $[\operatorname{Ir}(\mathrm{COD}) \mathrm{Cl}]_{2}(163$ $\mathrm{mg}, 0.244 \mathrm{mmol}$ ) was subsequently added. After $10 \mathrm{~min}$ of stirring, a yellow precipitate was formed. Hexane $(10 \mathrm{~mL})$ was added to complete the precipitation and the yellow solid was filtered to yield $[\operatorname{IrCl}(\mathrm{COD})(\mathrm{P}, \mathrm{SPh})] \quad(347 \quad \mathrm{~g}, \quad 86 \% \quad$ yield $) . \quad$ Elem. Anal., $\mathrm{C}_{37} \mathrm{H}_{37} \mathrm{ClFeIrPS} \cdot \mathrm{CH}_{2} \mathrm{Cl}_{2}$ (913.12): calcd. C 53.66, H 4.50; found C 53.83, H 4.53.

X-ray crystallography. Yellow single crystals of complexes $2-\mathbf{R}(\mathrm{R}=\mathrm{Et}, t \mathrm{Bu}, \mathrm{Ph})$ were obtained by slow diffusion of light hydrocarbon vapors (pentane for Et, hexane for $t \mathrm{Bu}$ and $\mathrm{Ph}$ ) into a $\mathrm{CH}_{2} \mathrm{Cl}_{2}$ solution. Diffusion of hexane vapors into a toluene solution of 2-Ph gave yellow crystals of compound 3-Ph. A single crystal of each compound was mounted under inert perfluoropolyether on the tip of glass fibre and cooled in the cryostream of either an Oxford-Diffraction XCALIBUR CCD diffractometer for 2-Ph, a Stoe IPDS diffractometer for 2Et or a Bruker SMART CCD diffractometer for $\mathbf{2 - t} \mathbf{B u}$ and 3. Data were collected using the monochromatic MoK $\alpha$ radiation $(\lambda=0.71073)$. The structures were solved by direct methods (SIR97) ${ }^{[80]}$ and refined by least-squares procedures on $F^{2}$ using SHELXL-97. ${ }^{[81]}$ All $\mathrm{H}$ atoms attached to carbon were introduced in calculation in idealised positions and treated as riding models. As indicated by the refinement of the Flack's parameter, ${ }^{[82]}$ compound 2-Et is 
twinned by inversion ('racemic twin'). In compound $\mathbf{3}$ a toluene solvent molecule is statistically disordered around an inversion center. The drawing of the molecules was realised with the help of ORTEP32. ${ }^{[83]}$ Crystal data and refinement parameters are shown in Table 7.

Crystallographic data (excluding structure factors) have been deposited with the Cambridge Crystallographic Data Centre as supplementary publication no. CCDC 283190 283193. Copies of the data can be obtained free of charge on application to the Director, CCDC, 12 Union Road, Cambridge CB2 1EZ, UK (fax: (+44) 1223-336-033; e-mail: deposit@ccdc.cam.ac.uk).

Supporting Information: (see footnote on the first page of this article). Procedures for fitting the equilibrium constant of Equation 1 to the experimental NMR data (Ir/1-Ph and Ir/1$\boldsymbol{t}$ Bu systems).

\section{Acknowledgments}

We are grateful to the EPSRC, the CNRS, and the European Union for funding under the HYDROCHEM network (contract HPRN-CT-2002-00176). 


\section{References}

[1] L. J. Yellowlees, K. G. Mcnamara, in Comprehensive Coordination Chemistry II, Vol. 6 (Eds.: J. A. McCleverty, T. J. Meyer), Elsevier, Oxford, 2004, pp. 147-246.

[2] R. H. Crabtree, Acc. Chem. Res. 1979, 12, 331-337.

[3] J. M. Brown, in Comprehensive Asymmetric Catalysis, Vol. 1 (Eds.: E. N. Jacobsen, A. Pfaltz, H. Yamamoto), Springer-Verlag, Berlin, 1999, pp. 121-182.

[4] W. Tang, X. Zhang, Chem. Rev. 2003, 103, 3029-3069.

[5] A. Lightfoot, P. Schnider, A. Pfaltz, Angew. Chem., Int. Ed. Engl. 1998, 37, 28972899.

[6] A. Pfaltz, J. Blankenstein, R. Hilgraf, E. Hormann, S. Mcintyre, F. Menges, M. Schonleber, S. P. Smidt, B. Wustenberg, N. Zimmermann, Adv. Synth. Catal. 2003, 345, 33-44.

[7] W. J. Drury, Iii, N. Zimmermann, M. Keenan, M. Hayashi, S. Kaiser, R. Goddard, A. Pfaltz, Angew. Chem., Int. Ed. Engl. 2004, 43, 70-74.

[8] T. Bunlaksananusorn, K. Polborn, P. Knochel, Angew. Chem., Int. Ed. Engl. 2003, 42, 3941-3943.

[9] P. Maire, S. Deblon, F. Breher, J. Geier, C. Boehler, H. Rueegger, H. Schoenberg, H. Gruetzmacher, Chem. Eur. J. 2004, 10, 4198-4205.

[10] K. Kaellstroem, C. Hedberg, P. Brandt, A. Bayer, P. G. Andersson, J. Am. Chem. Soc. 2004, 126, 14308-14309.

[11] D. Liu, Q. Dai, X. Zhang, Tetrahedron 2005, 61, 6460-6471.

[12] E. Guimet, M. Dieguez, A. Ruiz, C. Claver, J. Chem. Soc., Dalton Trans. 2005, 25572562.

[13] F. Spindler, B. Pugin, H. U. Blaser, Angew. Chem. Int. Ed. Engl. 1990, 29, 558-559.

[14] Y. Ng Cheong Chan, J. A. Osborn, J. Am. Chem. Soc. 1990, 112, 9400-9401.

[15] S. Kainz, A. Brinkmann, W. Leitner, A. Pfaltz, J. Am. Chem. Soc. 1999, 121, 64216429.

[16] D. Xiao, X. Zhang, Angew. Chem., Int. Ed. Engl. 2001, 40, 3425-3428.

[17] C. Blanc, F. Agbossou-Niedercorn, G. Nowogrocki, Tetrahedron: Asymmetry 2004, 15, 2159-2163.

[18] E. Guiu, C. Claver, J. Benet-Buchholz, S. Castillon, Tetrahedron: Asymmetry 2004, $15,3365-3373$.

[19] A. Trifonova, J. S. Diesen, C. J. Chapman, P. G. Andersson, Org. Lett. 2004, 6, 38253827.

[20] S. Vargas, M. Rubio, A. Suarez, A. Pizzano, Tetrahedron Lett. 2005, 46, 2049-2052.

[21] S.-M. Lu, X.-W. Han, Y.-G. Zhou, Adv. Synth. Catal. 2004, 346, 909-912.

[22] G. Zassinovich, G. Mestroni, S. Gladiali, Chem. Rev. 1992, 92, 1051-1069.

[23] M. J. Palmer, M. Wills, Tetrahedron: Asymmetry 1999, 10, 2045-2061.

[24] D. Mueller, G. Umbricht, B. Weber, A. Pfaltz, Helv. Chim. Acta 1991, 74, 232-240.

[25] R. Ter Halle, A. Breheret, E. Schulz, C. Pinel, M. Lemaire, Tetrahedron: Asymmetry 1997, 8, 2101-2108.

[26] D. G. I. Petra, P. C. J. Kamer, A. L. Spek, H. E. Schoemaker, P. W. N. M. Van Leeuwen, J. Org. Chem. 2000, 65, 3010-3017.

[27] J.-S. Chen, Y.-Y. Li, Z.-R. Dong, B.-Z. Li, J.-X. Gao, Tetrahedron Lett. 2004, 45, 8415-8418.

[28] Z.-R. Dong, Y.-Y. Li, J.-S. Chen, B.-Z. Li, Y. Xing, J.-X. Gao, Org. Lett. 2005, 7, 1043-1045.

[29] B. M. Trost, D. L. Van Vranken, Chem. Rev. 1996, 96, 395-422. 
[30] A. Pfalz, H. Yamamoto, J. M. Brown, in Comprehensive Asymmetric Catalysis, Vol. II (Eds.: E. N. Jacobsen, A. Pfaltz, H. Yamamoto), Springer-Verlag, Berlin, 1999, pp. 834-884.

[31] R. Takeuchi, Synlett 2002, 1954-1965.

[32] R. Takeuchi, M. Kashio, Angew. Chem., Int. Ed. Engl. 1997, 36, 263-265.

[33] B. Bartels, G. Helmchen, Chem. Commun. 1999, 741-742.

[34] C. Garcia-Yebra, J. P. Janssen, F. Rominger, G. Helmchen, Organometallics 2004, 23, 5459-5470.

[35] G. Lipowsky, N. Miller, G. Helmchen, Angew. Chem., Int. Ed. Engl. 2004, 43, 45954597.

[36] T. Ohmura, J. F. Hartwig, J. Am. Chem. Soc. 2002, 124, 15164-15165.

[37] A. Leitner, C. Shu, J. F. Hartwig, Org. Lett. 2005, 7, 1093-1096.

[38] N. Kinoshita, K. H. Marx, K. Tanaka, K. Tsubaki, T. Kawabata, N. Yoshikai, E. Nakamura, K. Fuji, J. Org. Chem. 2004, 69, 7960-7964.

[39] K. Tissot-Croset, D. Polet, A. Alexakis, Angew. Chem., Int. Ed. Engl. 2004, 43, 24262428.

[40] D. Polet, A. Alexakis, Org. Lett. 2005, 7, 1621-1624.

[41] H.-U. Blaser, Adv. Synth. Catal. 2002, 344, 17-31.

[42] H.-U. Blaser, W. Brieden, B. Pugin, F. Spindler, M. Studer, A. Togni, Topics in Catalysis 2002, 19, 3-16.

[43] T. Hayashi, M. Tanaka, I. Ogata, T. Kodama, T. Takahashi, Y. Uchida, T. Uchida, Bull. Chem. Soc. Jpn. 1983, 56, 1780-1785.

[44] T. Shibata, K. Yamashita, H. Ishida, K. Takagi, Org. Lett. 2001, 3, 1217-1219.

[45] R. Dorta, D. Broggini, R. Stoop, H. Ruegger, F. Spindler, A. Togni, Chem. Eur. J. 2004, 10, 267-278.

[46] G. Zassinovich, R. Bettella, G. Mestroni, N. Bresciani-Pahor, S. Geremia, L. Randaccio, J. Organomet. Chem. 1989, 370, 187-202.

[47] M. Shivakumar, J. Gangopadhyay, A. Chakravorty, Polyhedron 2001, 20, 2089-2093.

[48] C. M. Thomas, R. Mafua, B. Therrien, E. Rusanov, H. Stoeckli-Evans, G. Suss-Fink, Chem. Eur. J. 2002, 8, 3343-3352.

[49] J. J. Robertson, A. Kadziola, R. A. Krause, S. Larsen, Inorg. Chem. 1989, 28, 20972102.

[50] W. A. Herrmann, M. Elison, J. Fischer, C. Koecher, G. R. J. Artus, Chem. Eur. J. 1996, 2, 772-780.

[51] J. A. Mata, A. R. Chianese, J. R. Miecznikowski, M. Poyatos, E. Peris, J. W. Faller, R. H. Crabtree, Organometallics 2004, 23, 1253-1263.

[52] S. G. Murray, F. R. Hartley, Chem. Rev. 1981, 81, 365-414.

[53] J. R. Dilworth, N. Wheatley, Coord. Chem. Rev. 2000, 199, 89-158.

[54] J. C. Bayon, C. Claver, A. M. Masdeu-Bulto, Coord. Chem. Rev. 1999, 193-195, 73145 .

[55] A. M. Masdeu-Bulto, M. Dieguez, E. Martin, M. Gomez, Coord. Chem. Rev. 2003, 242, 159-201.

[56] L. Routaboul, S. Vincendeau, J.-C. Daran, E. Manoury, Tetrahedron: Asymmetry 2005, 16, 2685-2690.

[57] D. A. Evans, F. E. Michael, J. S. Tedrow, K. R. Campos, J. Am. Chem. Soc. 2003, 125, 3534-3543.

[58] M. Brym, C. Jones, Transition Met. Chem. 2003, 28, 595-599.

[59] A. R. Chianese, X. W. Li, M. C. Janzen, J. W. Faller, R. H. Crabtree, Organometallics 2003, 22, 1663-1667. 
[60] J. Browning, G. W. Bushnell, K. R. Dixon, R. W. Hilts, J. Organomet. Chem. 1993, 452, 205-218.

[61] G. Vasapollo, A. Sacco, C. F. Nobile, M. A. Pellinghelli, M. Lanfranchi, J. Organomet. Chem. 1986, 312, 249-262.

[62] E. Anzuela, M. A. Garralda, R. Hernandez, L. Ibarlucca, E. Pinilla, M. Angeles Monge, Inorg. Chim. Acta 1991, 185, 211-219.

[63] M. A. Garralda, R. Hernandez, L. Ibarlucea, M. I. Arriortua, M. K. Urtiaga, Inorg. Chim. Acta 1995, 232, 9-17.

[64] A. P. Martinez, M. P. Garcia, F. J. Lahoz, L. A. Oro, Inorg. Chim. Acta 2003, 347, 8698.

[65] P. Imhoff, C. J. Elsevier, J. Organomet. Chem. 1989, 361, C61-C65.

[66] S. Lo Schiavo, M. Grassi, G. De Munno, F. Nicolo, G. Tresoldi, Inorg. Chim. Acta 1994, 216, 209-216.

[67] C. Tejel, R. Bravi, M. A. Ciriano, L. A. Oro, M. Bordonaba, C. Graiff, A. Tiripicchio, A. Burini, Organometallics 2000, 19, 3115-3119.

[68] A. Molnar, A. Sarkany, M. Varga, J. Mol. Catal. A 2001, 173, 185-221.

[69] R. R. Schrock, J. A. Osborn, J. Am. Chem. Soc. 1976, 98, 2143-2147.

[70] F. Morandini, B. Longato, S. Bresadola, J. Organomet. Chem. 1982, 239, 377-384.

[71] M. Sodeoka, M. Shibasaki, J. Org. Chem. 1985, 50, 1147-1149.

[72] B. S. Nkosi, N. J. Coville, M. O. Albers, C. Gordon, M. M. Viney, E. Singleton, J. Organomet. Chem. 1990, 386, 111-119.

[73] M. W. Van Laren, C. J. Elsevier, Angew. Chem., Int. Ed. Engl. 1999, 38, 3715-3717.

[74] M. W. Van Laren, M. A. Duin, C. Klerk, M. Naglia, D. Rogolino, P. Pelagatti, A. Bacchi, C. Pelizzi, C. J. Elsevier, Organometallics 2002, 21, 1546-1553.

[75] J. W. Sprengers, J. Wassenaar, N. D. Clement, K. J. Cavell, C. J. Elsevier, Angew. Chem., Int. Ed. Engl. 2005, 44, 2026-2029.

[76] A. C. Cooper, K. G. Caulton, Inorg. Chim. Acta 1996, 251, 41-51.

[77] P. J. Albietz, Jr., B. P. Cleary, W. Paw, R. Eisenberg, J. Am. Chem. Soc. 2001, 123, 12091-12092.

[78] J. Kovacs, T. D. Todd, J. H. Reibenspies, F. Joo, D. J. Darensbourg, Organometallics 2000, 19, 3963-3969.

[79] T. Hayashi, T. Mise, M. Fukushima, M. Kagotani, N. Nagashima, Y. Hamada, A. Matsumoto, S. Kawakami, M. Konishi, K. Yamamoto, M. Kumada, Bull. Chem. Soc. Jpn. 1980, 53, 1138-1151.

[80] A. Altomare, M. Burla, M. Camalli, G. Cascarano, C. Giacovazzo, A. Guagliardi, A. Moliterni, G. Polidori, R. Spagna, J. Appl. Cryst. 1999, 32, 115-119.

[81] G. M. Sheldrick, SHELXL97. Program for Crystal Structure refinement, University of Göttingen, Göttingen, Germany, 1997.

[82] H. D. Flack, Acta Cryst. 1983, A39, 876-881.

[83] L. J. Farrugia, J. Appl. Crystallogr. 1997, 32, 565. 
Table 1. NMR properties of compounds $2-\mathrm{R}(\mathrm{R}=\mathrm{Et}, t \mathrm{Bu}, \mathrm{Ph})$ in $\mathrm{CDCl}_{3}$ solution. ${ }^{\mathrm{a}}$

2-Et

\begin{tabular}{|c|c|c|c|c|}
\hline${ }^{1} \mathrm{H}$ & $\mathrm{PPh}_{2}$ & $8.25(\mathrm{~m}, 2 \mathrm{H})$ & $8.02(\mathrm{~m}, 2 \mathrm{H})$ & $8.01(\mathrm{~d}, 2 \mathrm{H}(7))$ \\
\hline & & $7.58(\mathrm{~m}, 3 \mathrm{H})$ & $7.50-7.46(\mathrm{~m}, 5 \mathrm{H})$ & $7.66-7.61(\mathrm{~m}, 4 \mathrm{H})^{\mathrm{e}}$ \\
\hline & & $7.24(\mathrm{~s}, 3 \mathrm{H})$ & $7.37-7.35(\mathrm{~m}, 3 \mathrm{H})$ & $7.46-7.41(\mathrm{~m}, 3 \mathrm{H})^{\mathrm{e}}$ \\
\hline & & $7.05(\mathrm{~m}, 2 \mathrm{H})$ & & $7.27(\mathrm{~m}, 4 \mathrm{H})^{\mathrm{e}}$ \\
\hline & & & & $7.12-7.09(\mathrm{~m}, 2 \mathrm{H})^{\mathrm{e}}$ \\
\hline & $\mathrm{SCH}_{2}$ & $4.69(\mathrm{~d}, 1 \mathrm{H}(12))$ & $4.09(\mathrm{~d}, 1 \mathrm{H}(13))$ & $5.55(\mathrm{~d}, 1 \mathrm{H}(12))$ \\
\hline & & $3.97(\mathrm{~d}, 1 \mathrm{H}(12))$ & $3.87(\mathrm{~d}, 1 \mathrm{H}(13))$ & $4.09(\mathrm{br} \mathrm{s}, 2 \mathrm{H})^{\mathrm{f}}$ \\
\hline & $\mathrm{C}_{3} \mathrm{H}_{5}$ & $4.49(\mathrm{~s}, 1 \mathrm{H})$ & $4.64(\mathrm{~d}, 1 \mathrm{H}(2))$ & $4.44($ br s, $1 \mathrm{H})$ \\
\hline & & $4.22(\mathrm{~s}, 1 \mathrm{H})$ & $4.39(\mathrm{t}, 1 \mathrm{H}(2.5))$ & $4.25(\mathrm{t}, 1 \mathrm{H}(2.5))$ \\
\hline & & $4.00(\mathrm{~s}, 1 \mathrm{H})$ & $4.28(\mathrm{br} \mathrm{s}, 1 \mathrm{H})$ & $4.09(\mathrm{br} \mathrm{s}, 2 \mathrm{H})^{\mathrm{f}}$ \\
\hline & $\mathrm{Cp}$ & 3.83 & 4.11 & 3.82 \\
\hline & $\mathrm{COD}(\mathrm{CH})$ & $3.48-3.53(\mathrm{~m}, 4 \mathrm{H})^{\mathrm{b}}$ & 3.7 (broad, 4H)) & $3.32(\mathrm{t}, 2 \mathrm{H}(7))$ \\
\hline & & $2.96(\mathrm{~m}, 1 \mathrm{H})$ & & $3.09(\mathrm{~m}, 2 \mathrm{H})$ \\
\hline & & $2.86(\mathrm{~m}, 1 \mathrm{H})$ & & \\
\hline & $\mathrm{COD}\left(\mathrm{CH}_{2}\right)$ & $2.62(\mathrm{~m}, 2 \mathrm{H})$ & $2.33-2.28(\mathrm{~m}, 2 \mathrm{H})$ & $2.61-2.55(\mathrm{~m}, 2 \mathrm{H})$ \\
\hline & & $2.04(\mathrm{~m}, 4 \mathrm{H})$ & $2.13-2.11(\mathrm{~m}, 2 \mathrm{H})$ & $2.01-1.93(\mathrm{~m}, 4 \mathrm{H})$ \\
\hline & & $1.40(\mathrm{~m}, 5 \mathrm{H})^{\mathrm{c}}$ & $1.80-1.77(\mathrm{~m}, 2 \mathrm{H})$ & $1.35-1.32(\mathrm{~m}, 2 \mathrm{H})$ \\
\hline & & & $1.60-1.57(\mathrm{~m}, 2 \mathrm{H})$ & \\
\hline & $\mathrm{S} R$ & $3.48-3.53(\mathrm{~m}, 4 \mathrm{H})^{\mathrm{b}}$ & $1.42(\mathrm{~s}, 9 \mathrm{H})$ & e \\
\hline & & $1.40(\mathrm{~m}, 5 \mathrm{H})^{\mathrm{c}}$ & & \\
\hline${ }^{13} \mathrm{C}$ & Ph-ipso & $135.1(\mathrm{~d}(30))$ & $133.8(\mathrm{~d}(52))$ & $134.8(\mathrm{~d}(46))$ \\
\hline & & $133.3(\mathrm{~d}(51))$ & $132.6(\mathrm{~d}(50))$ & $134.0(\mathrm{~d}(51))$ \\
\hline & $\mathrm{Ph}-o, m, p$ & $135.4(\mathrm{~d}, 2 \mathrm{C}(13))$ & $135.2(\mathrm{~d}, 2 \mathrm{C}(11))$ & $132.3(\mathrm{~d}, 2 \mathrm{C}(9))$ \\
\hline & & $132.0(\mathrm{~d}, 2 \mathrm{C}(9))$ & $134.2(\mathrm{~d}, 2 \mathrm{C}(10))$ & $130.7(\mathrm{~d}, 2 \mathrm{C}(2))$ \\
\hline & & $130.6(\mathrm{~d}, 1 \mathrm{C}(2))$ & $130.1(\mathrm{~d}, 1 \mathrm{C}(2))$ & $128.9(\mathrm{~d}, 2 \mathrm{C}(2))$ \\
\hline & & $129.0(1 \mathrm{C})$ & $129.7(\mathrm{~d}, 1 \mathrm{C}(2))$ & $127.9(\mathrm{~d}, 2 \mathrm{C}(10))$ \\
\hline & & $127.8(\mathrm{~d}, 2 \mathrm{C}(10))$ & $127.6(\mathrm{~d}, 2 \mathrm{C}(10))$ & $127.0(\mathrm{~d}, 2 \mathrm{C}(9))$ \\
\hline & & $127.2(\mathrm{~d}, 2 \mathrm{C}(9))$ & $127.4(\mathrm{~d}, 2 \mathrm{C}(10))$ & \\
\hline & Cp & 70.6 & 71.0 & 70.7 \\
\hline & $C_{5} \mathrm{H}_{3}$ & $88.0(\mathrm{~d}, 1 \mathrm{C}(18))$ & $90.0(\mathrm{~d}, 1 \mathrm{C}(14))$ & $88.7(\mathrm{~d}, 1 \mathrm{C}(18))$ \\
\hline & & $72.6(\mathrm{~d}, 1 \mathrm{C}(7))$ & $74.9(\mathrm{~d}, 1 \mathrm{C}(8))$ & $72.3(\mathrm{~s}, 1 \mathrm{C})$ \\
\hline & & $72.5(\mathrm{~s}, 1 \mathrm{C})$ & $74.4(\mathrm{~d}, 1 \mathrm{C}(50))$ & $72.0(\mathrm{~d}, 1 \mathrm{C}(7))$ \\
\hline & & $70.3(\mathrm{~d}, 1 \mathrm{C}(38))$ & $71.3(\mathrm{~d}, 1 \mathrm{C}(17))$ & $71.0(\mathrm{~d}, 1 \mathrm{C}(43))$ \\
\hline & & $68.7(\mathrm{~d}, 1 \mathrm{C}(5))$ & $69.7(\mathrm{~d}, 1 \mathrm{C}(7))$ & $69.0(\mathrm{~d}, 1 \mathrm{C}(5))$ \\
\hline & $\mathrm{SCH}_{2}$ & 30.9 & 28.7 & 37.3 \\
\hline & $\mathrm{S} R$ & $66.8\left(\mathrm{CH}_{2}\right)$ & $43.6\left(C\left(\mathrm{CH}_{3}\right)\right)$ & $135.9(\mathrm{~d}, i \mathrm{C}(11))$ \\
\hline & & $13.5\left(\mathrm{CH}_{3}\right)$ & $30.9\left(\mathrm{C}_{\left.\left(\mathrm{CH}_{3}\right)\right)}\right.$ & $132.1(\mathrm{~s}, 2 \mathrm{C})$ \\
\hline & & & & $129.8(\mathrm{~s}, 1 \mathrm{C})$ \\
\hline & & & & $129.0(\mathrm{~s}, 2 \mathrm{C})$ \\
\hline & $\mathrm{COD}(\mathrm{CH})$ & $64.5(\mathrm{~d}, 2 \mathrm{C}(13))$ & d & $67.4(\mathrm{~s}, 2 \mathrm{C})$ \\
\hline & & $29.8(\mathrm{~d}, 2 \mathrm{C}(5))$ & & $65.1(\mathrm{~d}, 2 \mathrm{C}(15))$ \\
\hline & $\mathrm{COD}\left(\mathrm{CH}_{2}\right)$ & $35.8(\mathrm{~s}, 2 \mathrm{C})$ & $32.6(\mathrm{~s}, 2 \mathrm{C})$ & $35.5(\mathrm{~s}, 2 \mathrm{C})$ \\
\hline & & $28.6(\mathrm{~s}, 2 \mathrm{C})$ & $30.6(\mathrm{~s}, 2 \mathrm{C})$ & $28.7(\mathrm{~s}, 2 \mathrm{C})$ \\
\hline${ }^{31} \mathrm{P}$ & & -3.1 & 15.7 & -4.2 \\
\hline
\end{tabular}

${ }^{\mathrm{a}}$ Chemical shifts are reported as measured, for solutions containing ca. $10^{-2} \mathrm{~mol} / \mathrm{L}$ of the isolated crystals. ${ }^{b}$ Overlap between $\mathrm{COD}(\mathrm{CH})$ and $\mathrm{SEt}\left(\mathrm{CH}_{2}\right)$ resonances. ${ }^{\circ}$ Overlap between $\mathrm{COD}\left(\mathrm{CH}_{2}\right)$ and SEt $\left(\mathrm{CH}_{3}\right)$ resonances. ${ }^{\mathrm{d}}$ Not visible (see text). ${ }^{\mathrm{e} O v e r l a p}$ between the $\mathrm{PPh}_{2}$ and $\mathrm{SPh}$ resonances. ${ }^{\mathrm{f}} \mathrm{Ov}$ erlap between one $\mathrm{SCH}_{2}$ and one $\mathrm{C}_{5} \mathrm{H}_{3}$ resonance. 
Table 2. Selected bond distances $(\AA)$ and angled $\left(^{\circ}\right)$ for the pentacoordinated compounds 2-R ( $\mathrm{R}=\mathrm{Et}, \mathrm{Ph})$.

\begin{tabular}{|c|c|c|}
\hline & 2-Et & 2-Ph \\
\hline $\operatorname{Ir}(1)-\mathrm{CT} 01$ & $2.026(8)$ & $2.0216(9)$ \\
\hline Ir(1)-CT02 & $2.030(7)$ & $2.0433(8)$ \\
\hline $\mathrm{C}(30)-\mathrm{C}(31)$ & $1.441(10)$ & $1.445(4)$ \\
\hline $\mathrm{C}(34)-\mathrm{C}(35)$ & $1.407(11)$ & $1.395(4)$ \\
\hline $\operatorname{Ir}(1)-\mathrm{P}(1)$ & $2.3322(15)$ & $2.3289(13)$ \\
\hline $\operatorname{Ir}(1)-S(1)$ & $2.3928(17)$ & $2.3835(12)$ \\
\hline $\operatorname{Ir}(1)-\mathrm{Cl}(1)$ & $2.5739(19)$ & $2.5576(12)$ \\
\hline$P(1)-C(1)$ & $1.796(7)$ & $1.807(3)$ \\
\hline$P(1)-C(111)$ & $1.843(7)$ & $1.835(3)$ \\
\hline $\mathrm{P}(1)-\mathrm{C}(121)$ & $1.819(7)$ & $1.837(3)$ \\
\hline$S(1)-C(21)$ & $1.809(8)$ & $1.826(3)$ \\
\hline $\mathrm{S}(1)-\mathrm{C}(211)$ & $1.842(7)$ & $1.790(3)$ \\
\hline $\mathrm{C}(2)-\mathrm{C}(21)$ & $1.496(9)$ & $1.488(4)$ \\
\hline CT01-Ir(1)-СТ02 & $85.118(19)$ & $85.298(8)$ \\
\hline CT01-Ir(1)-P(1) & $153.2(4)$ & $156.06(2)$ \\
\hline CT02-Ir(1)-P(1) & $90.69(6)$ & $91.583(19)$ \\
\hline CT01-Ir(1)-S(1) & $90.3(3)$ & $90.020(18)$ \\
\hline CT02-Ir(1)-S(1) & $168.1(4)$ & $166.703(18)$ \\
\hline$P(1)-\operatorname{Ir}(1)-S(1)$ & $88.48(7)$ & $87.66(2)$ \\
\hline CT01-Ir(1)-Cl(1) & $115.4(3)$ & $113.814(19)$ \\
\hline CT02-Ir(1)-Cl(1) & $103.0(4)$ & $102.980(19)$ \\
\hline $\mathrm{P}(1)-\operatorname{Ir}(1)-\mathrm{Cl}(1)$ & $91.33(7)$ & $90.03(3)$ \\
\hline $\mathrm{S}(1)-\operatorname{Ir}(1)-\mathrm{Cl}(1)$ & $88.84(8)$ & $90.30(2)$ \\
\hline $\mathrm{C}(1)-\mathrm{P}(1)-\mathrm{C}(111)$ & $99.6(4)$ & $100.46(13)$ \\
\hline $\mathrm{C}(1)-\mathrm{P}(1)-\mathrm{C}(121)$ & $103.4(3)$ & $103.36(12)$ \\
\hline $\mathrm{C}(111)-\mathrm{P}(1)-\mathrm{C}(121)$ & $104.0(3)$ & $101.25(12)$ \\
\hline $\mathrm{C}(1)-\mathrm{P}(1)-\operatorname{Ir}(1)$ & $118.06(19)$ & $117.07(9)$ \\
\hline $\mathrm{C}(111)-\mathrm{P}(1)-\operatorname{Ir}(1)$ & $113.2(2)$ & $114.85(10)$ \\
\hline $\mathrm{C}(121)-\mathrm{P}(1)-\operatorname{Ir}(1)$ & $116.4(3)$ & 117.31(9) \\
\hline$C(21)-S(1)-C(211)$ & $94.5(3)$ & $98.62(13)$ \\
\hline $\mathrm{C}(211)-\mathrm{S}(1)-\operatorname{Ir}(1)$ & $110.7(3)$ & $112.14(9)$ \\
\hline$C(21)-S(1)-\operatorname{Ir}(1)$ & $108.8(3)$ & $108.09(10)$ \\
\hline $\mathrm{C}(2)-\mathrm{C}(1)-\mathrm{P}(1)$ & $126.8(4)$ & $127.2(2)$ \\
\hline $\mathrm{C}(5)-\mathrm{C}(1)-\mathrm{P}(1)$ & $126.5(5)$ & $126.0(2)$ \\
\hline$C(3)-C(2)-C(21)$ & $123.2(6)$ & $123.1(2)$ \\
\hline$C(1)-C(2)-C(21)$ & $128.8(6)$ & $128.7(2)$ \\
\hline $\mathrm{C}(2)-\mathrm{C}(21)-\mathrm{S}(1)$ & $114.8(5)$ & $111.23(18)$ \\
\hline $\mathrm{C}(116)-\mathrm{C}(111)-\mathrm{P}(1)$ & $118.9(6)$ & $121.6(2)$ \\
\hline $\mathrm{C}(112)-\mathrm{C}(111)-\mathrm{P}(1)$ & $121.8(6)$ & $120.1(2)$ \\
\hline $\mathrm{C}(126)-\mathrm{C}(121)-\mathrm{P}(1)$ & $119.9(6)$ & $118.9(2)$ \\
\hline $\mathrm{C}(122)-\mathrm{C}(121)-\mathrm{P}(1)$ & $122.4(6)$ & $122.1(2)$ \\
\hline $\mathrm{C}(216)-\mathrm{C}(211)-\mathrm{S}(1)$ & & $122.7(2)$ \\
\hline $\mathrm{C}(212)-\mathrm{C}(211)-\mathrm{S}(1)$ & & $116.9(2)$ \\
\hline
\end{tabular}


Table 3. Selected bond distances $(\AA)$ and angles $\left(^{\circ}\right)$ for the square planar compound 2-tBu.

$\begin{array}{llll}\operatorname{Ir}(1)-\mathrm{CT} 01 & 2.0859(6) & \operatorname{Ir}(1)-\mathrm{CT} 02 & 1.9988(5) \\ \operatorname{Ir}(1)-\mathrm{C}(30) & 2.204(2) & \operatorname{Ir}(1)-\mathrm{C}(34) & 2.131(3) \\ \operatorname{Ir}(1)-\mathrm{C}(31) & 2.194(2) & \operatorname{Ir}(1)-\mathrm{C}(35) & 2.110(3) \\ \operatorname{Ir}(1)-\mathrm{P}(1) & 2.3312(9) & \operatorname{Ir}(1)-\mathrm{Cl}(1) & 2.3625(8) \\ \mathrm{P}(1)-\mathrm{C}(1) & 1.811(3) & \mathrm{S}(1)-\mathrm{C}(21) & 1.818(3) \\ \mathrm{P}(1)-\mathrm{C}(111) & 1.831(3) & \mathrm{P}(1)-\mathrm{C}(121) & 1.835(3) \\ \mathrm{S}(1)-\mathrm{C}(22) & 1.828(3) & \mathrm{C}(30)-\mathrm{C}(31) & 1.392(4) \\ & & \mathrm{C}(34)-\mathrm{C}(35) & 1.418(4) \\ & & & \\ \mathrm{CT} 02-\operatorname{Ir}(1)-\mathrm{CT} 01 & 86.434(11) & \mathrm{P}(1)-\operatorname{Ir}(1)-\mathrm{Cl}(1) & 92.49(2) \\ \mathrm{CT} 01-\operatorname{Ir}(1)-\mathrm{P}(1) & 177.594(17) & \mathrm{CT} 02-\operatorname{Ir}(1)-\mathrm{P}(1) & 93.369(19) \\ \mathrm{CT} 01-\operatorname{Ir}(1)-\mathrm{Cl}(1) & 87.904(18) & \mathrm{CT} 02-\operatorname{Ir}(1)-\mathrm{Cl}(1) & 172.601(17) \\ \mathrm{C}(1)-\mathrm{P}(1)-\mathrm{C}(111) & 105.28(11) & \mathrm{C}(1)-\mathrm{P}(1)-\mathrm{C}(121) & 100.70(12) \\ \mathrm{C}(111)-\mathrm{P}(1)-\mathrm{C}(121) & 101.02(12) & \mathrm{C}(111)-\mathrm{P}(1)-\operatorname{Ir}(1) & 116.53(8) \\ \mathrm{C}(1)-\mathrm{P}(1)-\operatorname{Ir}(1) & 116.81(9) & \mathrm{C}(121)-\mathrm{P}(1)-\operatorname{Ir}(1) & 114.22(8) \\ \mathrm{C}(21)-\mathrm{S}(1)-\mathrm{C}(22) & 103.56(13 & \mathrm{C}(221)-\mathrm{C}(22)-\mathrm{S}(1) & 111.1(2) \\ \mathrm{C}(5)-\mathrm{C}(1)-\mathrm{P}(1) & 124.1(2) & \mathrm{C}(223)-\mathrm{C}(22)-\mathrm{S}(1) & 110.5(2) \\ \mathrm{C}(2)-\mathrm{C}(1)-\mathrm{P}(1) & 127.77(18) & \mathrm{C}(222)-\mathrm{C}(22)-\mathrm{S}(1) & 104.3(2) \\ \mathrm{C}(3)-\mathrm{C}(2)-\mathrm{C}(21) & 124.5(2) & \mathrm{C}(1)-\mathrm{C}(2)-\mathrm{C}(21) & 128.0(2) \\ \mathrm{C}(2)-\mathrm{C}(21)-\mathrm{S}(1) & 109.91(18) & & \\ \text { C(116)-C(111)-P(1) } & 120.86(19) & \mathrm{C}(126)-\mathrm{C}(121)-\mathrm{P}(1) & 120.8(2) \\ \text { C(112)-C(111)-P(1) } & 120.18(19) & \mathrm{C}(122)-\mathrm{C}(121)-\mathrm{P}(1) & 120.8(2)\end{array}$


Table 4. Selected bond distances $(\AA)$ and angles $\left(^{\circ}\right)$ for compounds 3-Ph.

\begin{tabular}{|c|c|c|c|}
\hline $\operatorname{Ir}(1)-\mathrm{CT} 01$ & $2.1242(2)$ & $\operatorname{Ir}(2)-\mathrm{CT} 03$ & $1.9807(2)$ \\
\hline $\operatorname{Ir}(1)-\mathrm{CT} 02$ & $2.0518(2)$ & $\operatorname{Ir}(2)-\mathrm{CT} 04$ & $1.9708(2)$ \\
\hline $\operatorname{Ir}(1)-C(30)$ & $2.239(5)$ & $\operatorname{Ir}(2)-C(40)$ & $2.094(6)$ \\
\hline $\operatorname{Ir}(1)-C(31)$ & $2.228(5)$ & $\operatorname{Ir}(2)-C(41)$ & $2.113(6)$ \\
\hline $\operatorname{Ir}(1)-C(34)$ & $2.171(5)$ & $\operatorname{Ir}(2)-C(43)$ & $2.086(5)$ \\
\hline $\operatorname{Ir}(1)-C(35)$ & $2.164(5)$ & $\operatorname{Ir}(2)-C(44)$ & $2.101(5)$ \\
\hline $\operatorname{Ir}(1)-\mathrm{P}(1)$ & $2.2820(13)$ & $\operatorname{Ir}(2)-\mathrm{Cl}(1)$ & $2.3644(13)$ \\
\hline $\operatorname{Ir}(1)-S(1)$ & $2.3280(12)$ & $\operatorname{Ir}(2)-\mathrm{Cl}(2)$ & $2.3706(13)$ \\
\hline $\mathrm{C}(30)-\mathrm{C}(31)$ & $1.381(7)$ & $\mathrm{C}(40)-\mathrm{C}(41)$ & $1.415(8)$ \\
\hline $\mathrm{C}(34)-\mathrm{C}(35)$ & $1.397(7)$ & $\mathrm{C}(43)-\mathrm{C}(44)$ & $1.414(8)$ \\
\hline $\mathrm{P}(1)-\mathrm{C}(1)$ & $1.806(5)$ & & \\
\hline $\mathrm{P}(1)-\mathrm{C}(111)$ & $1.828(5)$ & $\mathrm{P}(1)-\mathrm{C}(121)$ & $1.824(5)$ \\
\hline $\mathrm{C}(21)-\mathrm{S}(1)$ & $1.823(5)$ & $\mathrm{S}(1)-\mathrm{C}(211)$ & $1.786(5)$ \\
\hline CT02-Ir(1)-СТ01 & $85.612(7)$ & СТ04-Ir(2)-СТ03 & $88.285(9)$ \\
\hline CT01-Ir(1)-P(1) & $173.43(3)$ & CT03-Ir(2)-Cl(1) & $90.96(4)$ \\
\hline CT01-Ir(1)-S(1) & 89.93(3) & CT04-Ir(2)-Cl(1) & $177.05(4)$ \\
\hline CT02-Ir(1)-P(1) & $92.99(3)$ & CT03-Ir(2)-Cl(2) & $177.63(3)$ \\
\hline CT02-Ir(1)-S(1) & $170.56(3)$ & CT04-Ir(2)-Cl(2) & $90.72(3)$ \\
\hline $\mathrm{P}(1)-\operatorname{Ir}(1)-\mathrm{S}(1)$ & $92.35(4)$ & $\mathrm{Cl}(1)-\operatorname{Ir}(2)-\mathrm{Cl}(2)$ & $90.14(5)$ \\
\hline $\mathrm{C}(1)-\mathrm{P}(1)-\mathrm{C}(111)$ & $102.6(2)$ & $\mathrm{C}(1)-\mathrm{P}(1)-\mathrm{C}(121)$ & $103.6(2)$ \\
\hline $\mathrm{C}(121)-\mathrm{P}(1)-\mathrm{C}(111)$ & $105.2(2)$ & $\mathrm{C}(121)-\mathrm{P}(1)-\operatorname{Ir}(1)$ & $118.79(17)$ \\
\hline C(1)-P(1)-Ir(1) & $114.86(16)$ & $\mathrm{C}(111)-\mathrm{P}(1)-\operatorname{Ir}(1)$ & $110.19(16)$ \\
\hline $\mathrm{C}(2)-\mathrm{C}(1)-\mathrm{P}(1)$ & $122.4(4)$ & $\mathrm{C}(5)-\mathrm{C}(1)-\mathrm{P}(1)$ & $129.0(4)$ \\
\hline$C(1)-C(2)-C(21)$ & $126.4(4)$ & $\mathrm{C}(2)-\mathrm{C}(21)-\mathrm{S}(1)$ & $111.9(3)$ \\
\hline $\mathrm{C}(112)-\mathrm{C}(111)-\mathrm{P}(1)$ & $121.5(4)$ & $\mathrm{C}(122)-\mathrm{C}(121)-\mathrm{P}(1)$ & $117.9(4)$ \\
\hline $\mathrm{C}(116)-\mathrm{C}(111)-\mathrm{P}(1)$ & 119.1(4) & $\mathrm{C}(126)-\mathrm{C}(121)-\mathrm{P}(1)$ & $123.2(4)$ \\
\hline $\mathrm{C}(211)-\mathrm{S}(1)-\mathrm{C}(21)$ & $100.5(2)$ & $\mathrm{C}(216)-\mathrm{C}(211)-\mathrm{S}(1)$ & $117.7(4)$ \\
\hline$C(211)-S(1)-\operatorname{Ir}(1)$ & $108.55(17)$ & $\mathrm{C}(21)-\mathrm{S}(1)-\operatorname{Ir}(1)$ & $115.67(17)$ \\
\hline $\mathrm{C}(212)-\mathrm{C}(211)-\mathrm{S}(1)$ & $121.5(4)$ & & \\
\hline
\end{tabular}


Table 5. ${ }^{31} \mathrm{P}$ resonances assigned to the products of $1: 1$ and $2: 1$ ligand $\mathbf{1}-\mathbf{R}$ addition to $[\mathrm{M}(\mathrm{COD}) \mathrm{Cl}]_{2}\left(\right.$ solvent $\left.=\mathrm{CDCl}_{3}\right)$.

\begin{tabular}{lccc}
\multicolumn{1}{c}{ Complex } & \multicolumn{3}{c}{$\delta{ }^{31} \mathrm{P}\left(\mathrm{J}_{\mathrm{PRh}}\right)$} \\
& 1-R:M ratio & $\mathrm{M}=\mathrm{Rh}$ & $\mathrm{M}=\mathrm{Ir}^{\mathrm{a}}$ \\
\hline $\mathrm{M}(\mathrm{COD}) \mathrm{Cl}(\mathrm{P}, \mathrm{SEt})$ & $1: 1$ & 5-Et: $25.2(142 \mathrm{~Hz})$ & 2-Et: -4.6 \\
$\mathrm{M}(\mathrm{COD}) \mathrm{Cl}(\mathrm{P}, \mathrm{S} t \mathrm{Bu})$ & $1: 1$ & 5-tBu: $24.5(147 \mathrm{~Hz})$ & 2-t $\mathbf{B u}: 15.6$ \\
$\mathrm{M}(\mathrm{COD}) \mathrm{Cl}(\mathrm{P}, \mathrm{SPh})$ & $1: 1$ & $\mathbf{5 - P h :} 22.2(143 \mathrm{~Hz})$ & 2-Ph: -2.9 \\
{$[\mathrm{M}(\mathrm{COD})(\mathrm{P}, \mathrm{SPh})]\left[\mathrm{M}(\mathrm{COD}) \mathrm{Cl}_{2}\right]$} & $1: 2$ & $\mathbf{6 - P h}: 24.0(143 \mathrm{~Hz})$ & $\mathbf{3 - P h :} 11.0$
\end{tabular}

${ }^{\text {a}}$ Following the chemical shift analysis as a function of 1-R/M ratio, as outlined in the text and described in detail in the Supporting Information. 
Table 6. Diphenylacetylene hydrogenation in presence of complexes 2-Ph and 2-tBu.

\begin{tabular}{|c|c|c|c|c|c|c|}
\hline Entry & complex & $\begin{array}{l}\text { Reaction } \\
\text { time }\end{array}$ & Conversion $^{\mathrm{a}, \mathrm{b}}$ & $\begin{array}{l}\text { Yield of } \text { cis - } \\
\text { stilbene }\end{array}$ & $\begin{array}{l}\text { Yield of trans- } \\
\text { stilbene }\end{array}$ & $\begin{array}{c}\text { Yield of 1,2- } \\
\text { diphenylethane }\end{array}$ \\
\hline 1 & 2-Ph & $6 h$ & $59 \%$ & $79 \%$ & $8 \%$ & $13 \%$ \\
\hline 2 & $2-t \mathrm{Bu}$ & $6 \mathrm{~h}$ & $100 \%$ & $64 \%$ & $14 \%$ & $22 \%$ \\
\hline
\end{tabular}

${ }^{a}$ Reaction run with $1 \mathrm{mmol}$ of diphenylacetylene, $0.01 \mathrm{mmol}$ of complex 2 (1 mol\%) in $2 \mathrm{~mL}$ $\mathrm{CH}_{2} \mathrm{Cl}_{2}$ at room temperature under 30 bars of dihydrogen. ${ }^{\mathrm{b}}$ Determined by GC. 
Table 7. Crystal data and structure refinement for all compounds.

\begin{tabular}{|c|c|c|c|c|}
\hline Identification code & 2-Et & 2-Ph & $2-t \mathrm{Bu}$ & 3-Ph \\
\hline Empirical formula & $\mathrm{C}_{33} \mathrm{H}_{37} \mathrm{ClFeIrPS} \cdot \mathrm{CH}_{2} \mathrm{Cl}_{2}$ & $\mathrm{C}_{37} \mathrm{H}_{37} \mathrm{ClFeIrPS} \cdot \mathrm{CH}_{2} \mathrm{Cl}_{2}$ & $\mathrm{C}_{35} \mathrm{H}_{41} \mathrm{ClFeIrPS} \cdot \mathrm{CH}_{2} \mathrm{Cl}_{2}$ & $\mathrm{C}_{45} \mathrm{H}_{49} \mathrm{Cl}_{2} \mathrm{FeIr}{ }_{2} \mathrm{PS} \cdot\left(\mathrm{C}_{7} \mathrm{H}_{8}\right)_{0.5}$ \\
\hline Formula weight & 865.08 & 913.12 & 893.13 & 1210.09 \\
\hline Temperature, $\mathrm{K}$ & $180(2)$ & $180(2)$ & $115(2)$ & $105(2)$ \\
\hline Wavelength, $\AA$ & 0.71073 & 0.71073 & 0.71073 & 0.71073 \\
\hline Crystal system & Monoclinic & Triclinic & Orthorhombic & Triclinic \\
\hline Space group & $\mathrm{P} 2_{1}$ & P - 1 & Pbca & P -1 \\
\hline a, $\AA$ & $11.6753(13)$ & $10.177(5)$ & $14.778(5)$ & $10.1650(8)$ \\
\hline $\mathrm{b}, \AA$ & $10.9974(9)$ & $12.983(5)$ & $19.216(6)$ & $13.4775(11)$ \\
\hline c, $\AA$ & $12.7284(13)$ & $13.676(5)$ & $24.110(8)$ & $16.7698(13)$ \\
\hline$\alpha, \circ$ & 90.0 & $102.045(5)$ & 90.0 & $81.296(2)$ \\
\hline$\beta, \circ$ & $100.717(13)$ & $93.653(5)$ & 90.0 & $72.575(2)$ \\
\hline$\gamma,^{\circ}$ & 90.0 & $102.670(5)$ & 90.0 & $78.406(2)$ \\
\hline Volume, $\AA^{3}$ & $1605.8(3)$ & $1712.8(12)$ & $6847(4)$ & 2137.1(3) \\
\hline $\mathrm{Z}$ & 2 & 2 & 8 & 2 \\
\hline Density (calcd), $\mathrm{Mg} / \mathrm{m}^{3}$ & 1.789 & 1.771 & 1.733 & 1.881 \\
\hline Absorption coefficient, $\mathrm{mm}^{-1}$ & 4.980 & 4.674 & 4.675 & 6.792 \\
\hline $\mathrm{F}(000)$ & 856 & 904 & 3552 & 1178 \\
\hline Crystal size, $\mathrm{mm}^{3}$ & $0.22 \times 0.17 \times 0.01$ & $0.20 \times 0.12 \times 0.055$ & $0.35 \times 0.12 \times 0.03$ & $0.22 \times 0.19 \times 0.07$ \\
\hline Theta range, ${ }^{\circ}$ & 2.17 to 26.14 & 3.30 to 32.05 & 1.93 to $28.40^{\circ}$. & 2.10 to 28.32 \\
\hline Reflections collected & 12676 & 18279 & 66063 & 22207 \\
\hline Independent reflections [R(int)] & $6263(0.0500)$ & $10876(0.0311)$ & $8540(0.0483)$ & $10541(0.0312)$ \\
\hline Completeness, $\%$ & $98.5 \%$ & $90.3 \%$ & $99.2 \%$ & $98.8 \%$ \\
\hline Absorption correction & Multi-scan & Analytical & SADABS & SADABS \\
\hline Max., min. transmission & 0.6451 and 0.5709 & 0.64910 and 0.24012 & 1.000 and 0.724635 & 1.0 and 0.812 \\
\hline Refinement method & $\mathrm{F}^{2}$ & $\mathrm{~F}^{2}$ & $\mathrm{~F}^{2}$ & $\mathrm{~F}^{2}$ \\
\hline Data / restraints / parameters & 6263 / 395 / 372 & 10876 / 0 / 406 & $8540 / 0$ / 391 & $10541 / 55 / 498$ \\
\hline Goodness-of-fit on $\mathrm{F}^{2}$ & 0.967 & 0.914 & 1.031 & 1.041 \\
\hline Final R indices [I $>2 \operatorname{sigma}(\mathrm{I})]$ & $\begin{array}{l}\mathrm{R} 1=0.0326 \\
\mathrm{wR} 2=0.0682\end{array}$ & $\begin{array}{l}\mathrm{R} 1=0.0304, \\
\mathrm{wR} 2=0.0494\end{array}$ & $\begin{array}{l}\mathrm{R} 1=0.0241, \\
\mathrm{wR} 2=0.0534\end{array}$ & $\mathrm{R} 1=0.0358, \mathrm{wR} 2=0.0815$ \\
\hline $\mathrm{R}$ indices (all data) & $\begin{array}{l}\mathrm{R} 1=0.0437 \\
\mathrm{wR} 2=0.0714\end{array}$ & $\begin{array}{l}\mathrm{R} 1=0.0415 \\
\mathrm{wR} 2=0.0516\end{array}$ & $\begin{array}{l}\mathrm{R} 1=0.0335 \\
\mathrm{wR} 2=0.0569\end{array}$ & $\mathrm{R} 1=0.0456, w \mathrm{R} 2=0.0855$ \\
\hline Absolute structure parameter & $0.571(7)$ & & & \\
\hline Largest diff. peak and hole, e. $\AA^{-3}$ & 1.141 and $-0.817 \mathrm{e} . \AA^{-3}$ & 2.188 and $-1.362 \mathrm{e} . \AA^{-3}$ & 1.831 and -0.749 e. $\AA^{-3}$ & 4.945 and $-1.048 \mathrm{e} . \AA^{-3}$ \\
\hline
\end{tabular}




\section{Captions}

Figure 1. ORTEP views of the molecular structures of compounds 2-Et (a); 2-tBu (b) and 2-Ph (c). Ellipsoids are drawn at the 50\% probability level and hydrogen atoms are omitted for clarity.

Figure 2. ORTEP view of the molecular structures of compounds 3-Ph. Ellipsoids are drawn at the $50 \%$ probability level and hydrogen atoms are omitted for clarity.

Figure 3. Dependence of the chemical shift of a few resonance for the $[\operatorname{Ir}(\mathrm{COD}) \mathrm{Cl}]_{2} / \mathbf{1}-\mathbf{P h}$ system on the 1-Ph/Ir ratio. (a) ${ }^{31} \mathrm{P}$ resonance; (b) ${ }^{1} \mathrm{H}$ resonances: unsubstituted $\mathrm{Cp}\left(5 \mathrm{H}\right.$, diamonds); substituted $\mathrm{Cp}(1 \mathrm{H}$, circles $)$; $\mathrm{CH}_{2}(1 \mathrm{H}$, squares; $1 \mathrm{H}$, triangles). The solid lines are obtained by fitting the data according to Scheme 1 (see text).

Figure 4. Chemical shift (a) and relative ratio (b) of the ${ }^{31} \mathrm{P}$ NMR resonances for the $[\operatorname{Ir}(\mathrm{COD}) \mathrm{Cl}]_{2} / \mathbf{1 - t} \mathbf{B u}$ system as a function of the 1-t $\mathbf{B u} /$ Ir ratio. Squares: rapidly equilibrating mixture of 2-t $\mathbf{B u}$ and 3-t $\mathbf{B u}$; triangles: 4-t $\mathbf{B u}$; diamonds: 1-t $\mathbf{B u}$. The solid line in (a) is the data fit to the model of Scheme 2 (see text). 
Figure 1
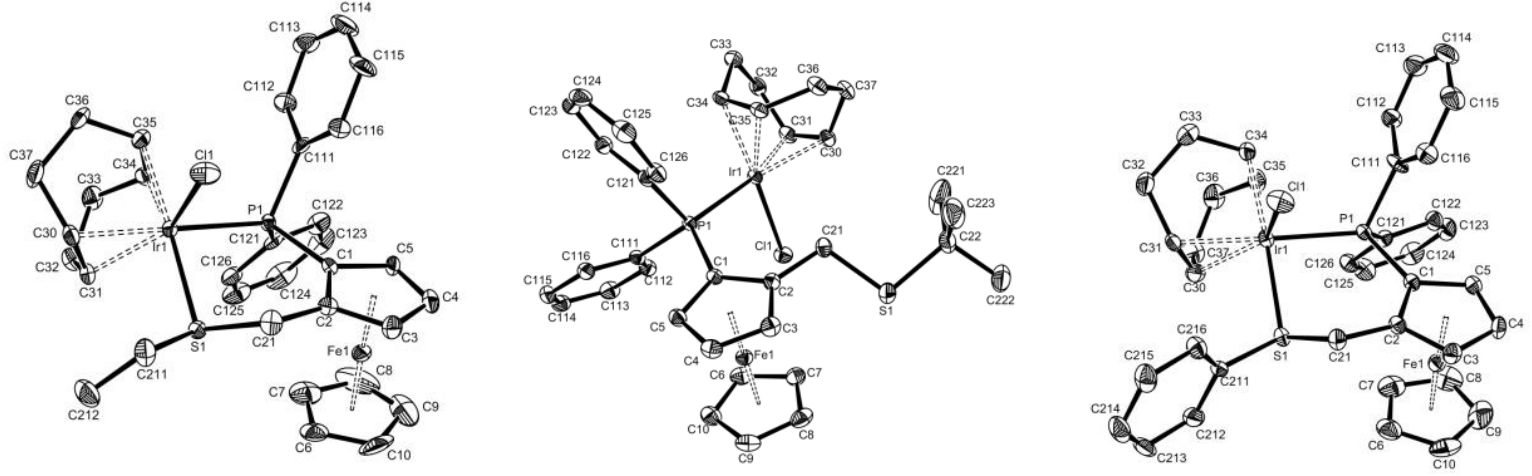

Figure 2
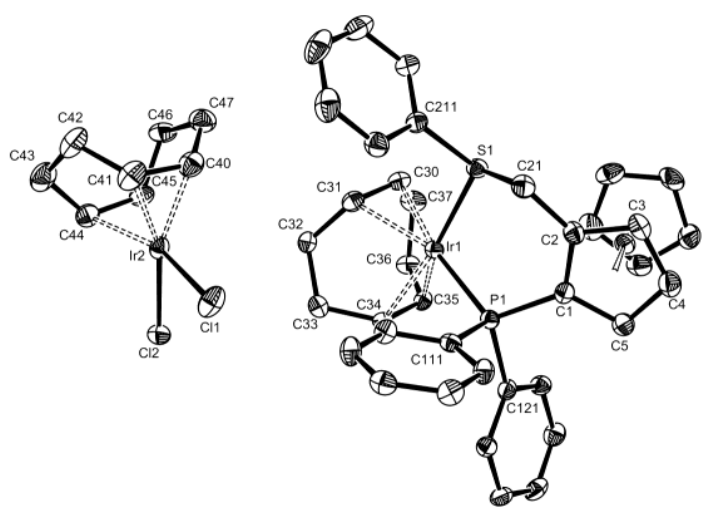

Figure 3
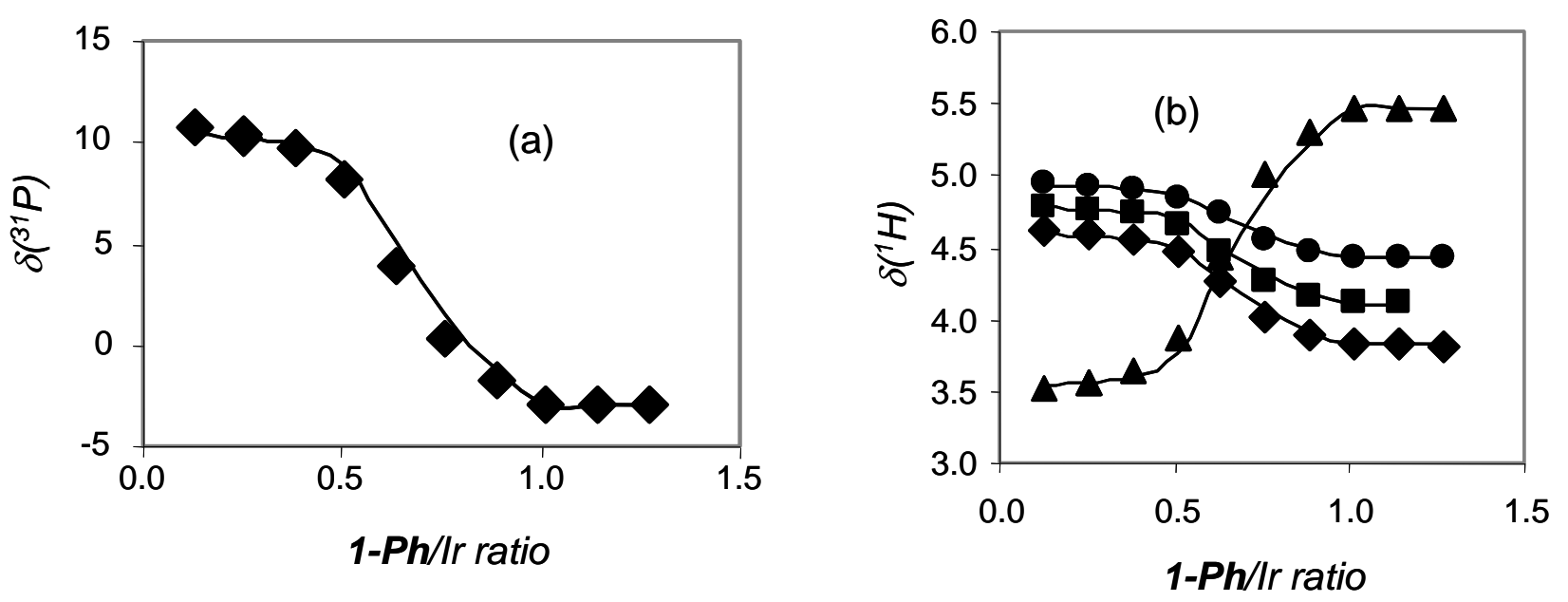
Figure 4
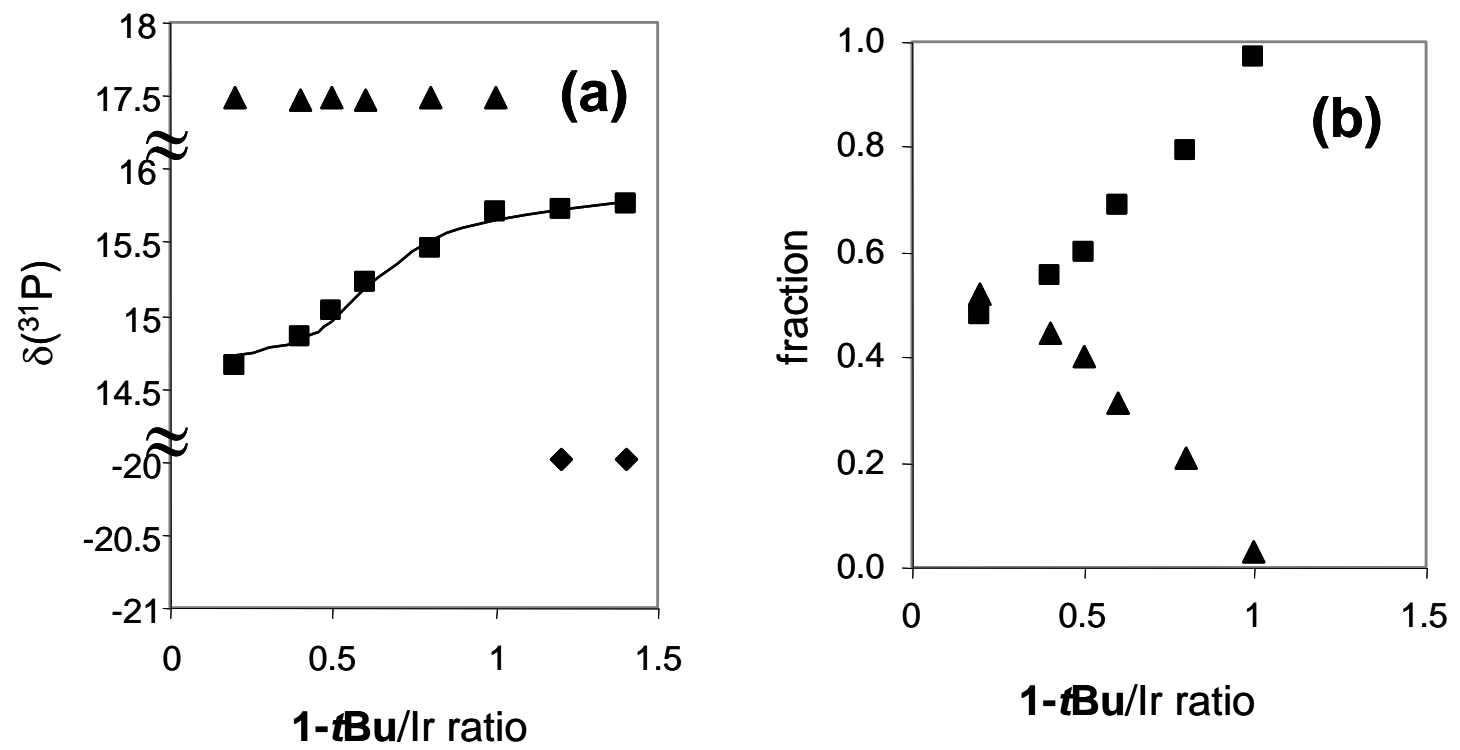

Scheme 3

$[\operatorname{Ir}(\mathrm{COD}) \mathrm{Cl}]_{2}+\mathrm{P}, \mathrm{SPh} \longrightarrow\left[\operatorname{Ir}(\mathrm{COD})\left(\kappa^{2}-\mathrm{P}, \mathrm{SPh}\right)\right]^{+}\left[\operatorname{Ir}(\mathrm{COD}) \mathrm{Cl}_{2}\right]^{-}$

1-Ph

3-Ph

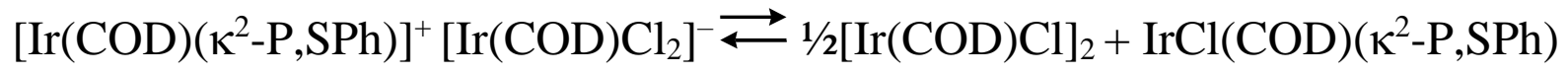

3-Ph

2-Ph 
Scheme 2

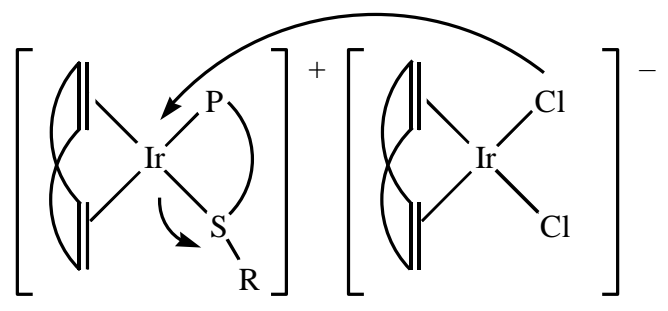

3-R
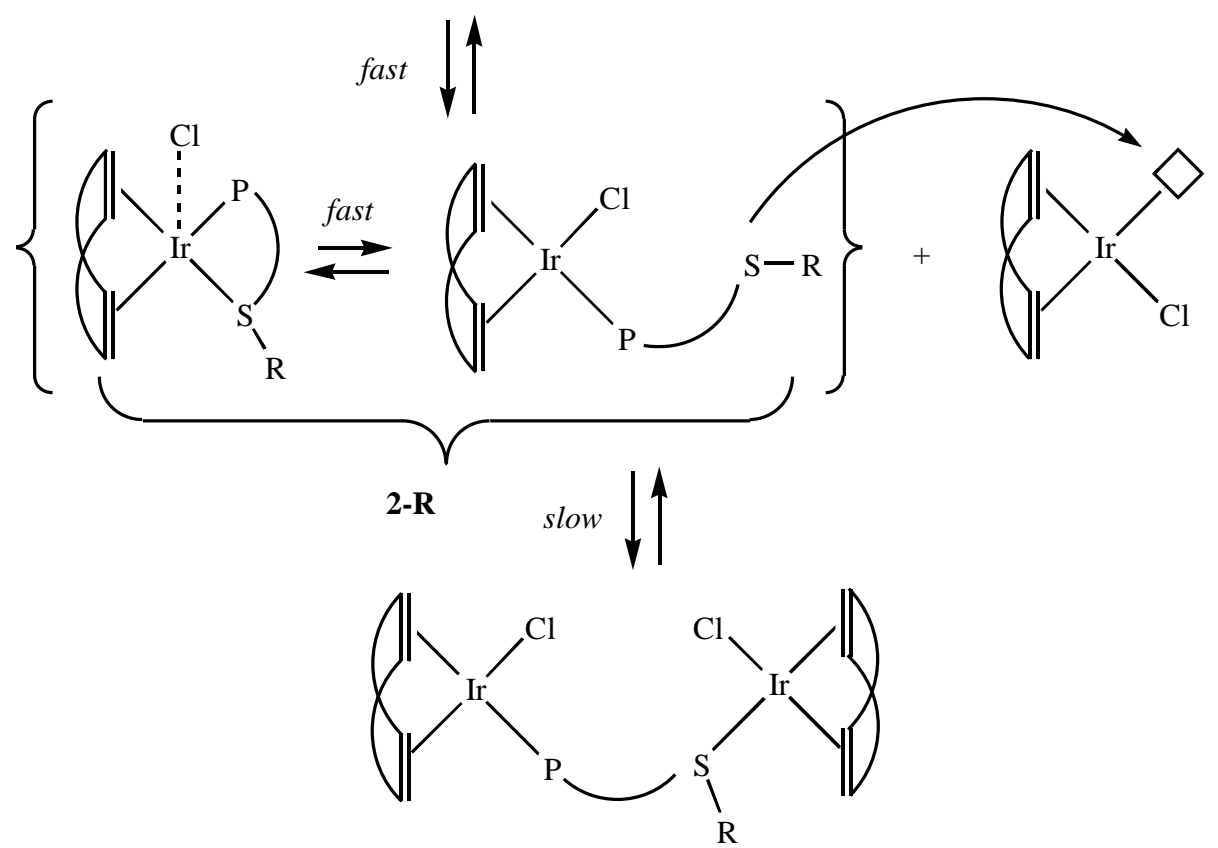

4-R 


$$
\left[(\mathrm{COD}) \operatorname{Ir}(\mu-\mathrm{Cl})_{2} \operatorname{Ir}(\mathrm{COD})\right]+2(\mathrm{P}, \mathrm{SR}) \longrightarrow 2 \operatorname{IrCl}(\mathrm{COD})(\mathrm{P}, \mathrm{SR})
$$

\section{1-R 2-R}

Equation 7

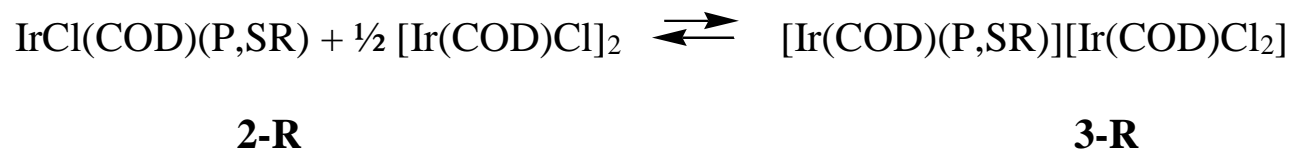

Equation 8

$$
\mathrm{K}=\frac{[\mathbf{2}-\mathbf{R}]\left[\mathrm{Ir}_{2} \mathrm{Cl}_{2}(\mathrm{COD})_{2}\right]^{1 / 2}}{[\mathbf{3}-\mathbf{R}]}
$$

Equation 9

$$
\delta_{\text {calc }}=\delta 2-\mathbf{R}[2-\mathbf{R}] /([2-\mathbf{R}]+[3-\mathbf{R}])+\delta 3-\mathbf{R}[3-\mathbf{R}] /([2-\mathbf{R}]+[3-\mathbf{R}])
$$

Equation 10

$\left.\underset{\mathbf{5}-\mathbf{P h}}{\mathrm{RhCl}(\mathrm{COD})(\mathrm{P}, \mathrm{SPh})}+\frac{1 / 2[\operatorname{Ir}(\mathrm{COD}) \mathrm{Cl}]_{2}}{\longrightarrow} \underset{\mathbf{2}-\mathbf{P h}}{\left[\operatorname{Ir}(\mathrm{COD})\left(\kappa^{2}-\mathrm{P}, \mathrm{SPh}\right) \mathrm{Cl}\right]}+\underset{1 / 2}{\operatorname{Rh}}(\mathrm{COD}) \mathrm{Cl}\right]_{2}$

Equation 11

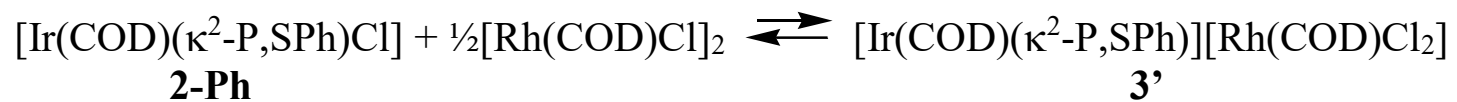

Equation 12 